NBER WORKING PAPER SERIES

\title{
REALIZING THE GAINS FROM TRADE: EXPORT CROPS, MARKETING COSTS, AND POVERTY
}

\author{
Jorge Balat \\ Irene Brambilla \\ Guido Porto \\ Working Paper 13395 \\ http://www.nber.org/papers/w13395 \\ NATIONAL BUREAU OF ECONOMIC RESEARCH \\ 1050 Massachusetts Avenue \\ Cambridge, MA 02138 \\ September 2007
}

We thank J. Muwonge at the Uganda Bureau Of Statistics (UBOS) for assistance with the data and D. Merotto and H. Tang at the World Bank for encouragement and support. We thank H. Ennis, P. Goldberg, A. Harrison and M. McMillan for detailed comments, and seminar participants at Duke, NBER, Penn State, and University of Connecticut. This paper was supported by a DECRG Research Support Budget grant and two Dfid projects on trade and services and on trade facilitation. All errors are our responsibility. The views expressed herein are those of the author(s) and do not necessarily reflect the views of the National Bureau of Economic Research.

(C) 2007 by Jorge Balat, Irene Brambilla, and Guido Porto. All rights reserved. Short sections of text, not to exceed two paragraphs, may be quoted without explicit permission provided that full credit, including $\odot$ notice, is given to the source. 
Realizing the Gains From Trade: Export Crops, Marketing Costs, and Poverty

Jorge Balat, Irene Brambilla, and Guido Porto

NBER Working Paper No. 13395

September 2007, Revised March 2009

JEL No. F10,F14

\begin{abstract}
$\underline{\text { ABSTRACT }}$
This paper explores the role of export costs in the process of poverty reduction in rural Africa. We claim that the marketing costs that emerge when the commercialization of export crops requires intermediaries can lead to lower participation into export cropping and, thus, to higher poverty. We test the model using data from the Uganda National Household Survey. We show that: i) farmers living in villages with fewer outlets for sales of agricultural exports are likely to be poorer than farmers residing in market-endowed villages; ii) market availability leads to increased household participation in export cropping (coffee, tea, cotton, fruits); iii) households engaged in export cropping are less likely to be poor than subsistence-based households. We conclude that the availability of markets for agricultural export crops help realize the gains from trade. This result uncovers the role of complementary factors that provide market access and reduce marketing costs as key building blocks in the link between the gains from export opportunities and the poor.
\end{abstract}

Jorge Balat

Yale University

Department of Economics

28 Hilllhouse

P. O. Box 208264

New Haven, CT 06520-8264

jorge.balat@yale.edu

Irene Brambilla

Yale University

Department of Economics

37 Hilllhouse

P. O. Box 208264

New Haven, CT 06520-8264

and NBER

irene.brambilla@yale.edu

\author{
Guido Porto \\ Universidad Nacional de La Plata \\ Argentina \\ guido.porto@depeco.econo.unlp.edu.ar
}




\section{Introduction}

Trade costs, which include international transportation costs, transaction costs, and distribution costs in countries of origin, destination, and transit, are an important barrier to trade. Estimates from Anderson and van Wincoop (2004) and Hummels (2001) indicate that these costs can in fact be much larger than tariffs and other trade policy barriers. Even in places where formal trade barriers are almost fully eliminated, trade costs still remain as strong barriers to exports and imports.

Trade costs prevent the full realization of the gains from trade. In developing countries, these costs can also wither the poverty alleviation role of export opportunities. ${ }^{1}$ In addition, some of the costs associated with exports, and thus the impacts of trade on incomes and poverty, depend to a large extent on complementary domestic factors like improved infrastructure, adequate competition policies and, especially in Africa, enhanced access to credit, better education and health, and low marketing or intermediation costs.

In this paper, we explore the costs of trade for domestic producers when exporting requires intermediaries, a widespread phenomenon in many developing countries. The need for intermediaries in export activities can generate wide marketing costs in agriculture. ${ }^{2}$ The focus of our investigation is intermediation costs in export crops in Uganda. Specifically, we claim here that, in rural Uganda, the lack of local outlets for export crops like coffee, tea, and cotton raises their marketing costs, prevents the adoption of high-return crops in favor of subsistence crops like maize or matooke, and impedes farmers to take full advantage of high export prices and enhanced market access opportunities abroad. ${ }^{3}$

We begin by developing a model of agricultural production with marketing costs. The

\footnotetext{
${ }^{1}$ See the reviews in Winters, McCulloch and Mckay (2004) and Goldberg and Pavcnic (2007).

${ }^{2}$ These marketing costs are non-traditional trade costs like those in Limão and Venables (2001), who analyze trade costs beyond transportation costs. They show that the total cost of transportation depends on the level of infrastructure of trading partners.

${ }^{3}$ There is an increasing interest in the complementarities between trade and domestic factors. Three recent edited volumes on trade and poverty, Harrison (2007), Hertel and Winters (2006), and Hoekman and Olarreaga (2007), testify to this. A few more specific examples include Porto (2005), who shows that informal barriers to trade have significant effects on poverty in Moldova; Welch, McMillan, and Rodrik (2003), who argue that the negative impacts of the liberalization of the cashew sector in Mozambique was mainly due to the structure of the internal markets; Nicita (2008), who studies policies that facilitate the transmission of international prices to the household in Mexico; and Ashraf, Giné and Karlan (2008), who assess the effectiveness of DrumNet in the presence of quality requirement for exports in Kenya.
} 
model shows how farmers may be prevented from engaging in exporting activities, and thus from earning higher income, when local marketing costs are too high. We then test this hypothesis using farming data from Uganda (the Uganda National Household Survey). We combine household-level information on income, poverty and exporting activities with village-level measures of availability of local agricultural export markets. These markets include a variety of outlets: standard district markets and road stalls; export intermediaries (truck services and farm-gate buyers); and foreign direct investment in the form of commercial tea and coffee plantations.

Our empirical analysis establishes a negative relationship between local availability of export markets and poverty: controlling for all the relevant household and district determinants and taking account of endogeneity issues, we find that the presence of export markets leads to lower poverty in rural Uganda. We explore the exports mechanism behind this link: we find that export markets act as a facilitator of export agriculture cropping (households may be prevented from entering export cash cropping if trading costs are too high) and that poverty among producers of export crops is lower than poverty among subsistence farmers (major export crops have higher returns than food crops). Overall, we establish that lower export marketing costs induce export crop participation, which raises household income and decreases the likelihood of poverty.

It is not surprising that domestic factors affect poverty and agricultural earnings. One of the merits of our investigation is the finding of complementarities between those domestic factors and the export opportunities: without domestic factors, the gains from trade may not be realizable but, without exports, some domestic factors may become less relevant for poverty alleviation. In addition, we identify one specific, and potentially important, factor among these complementarities, namely the marketing costs of export crops. ${ }^{4}$ In fact, the reduction in poverty resulting from increased export market availability can be sizeable. Back of the envelope calculations show that equivalent poverty-reducing impacts could only be generated by large increases in the international and farm-gate prices of export

\footnotetext{
${ }^{4}$ While we focus on trade costs, our approach is related to the work of Goyal (2008) and Jensen (2007), who explore the role of improved marketing information (via cell phones or internet kiosks) on export adoption by farmers. See Collier and Gunning (1999) for a thorough description of various major constraints to development in Africa.
} 
crops arising, for example, from enhanced market access to developed countries. Hence, the Uganda case is an instance where the standard prescriptions of education and health policies could be combined with more specific measures to encourage the development of local export markets (for example via the "aid for trade" paradigm) in a successful attempt towards poverty reduction.

The paper is organized as follows. In section 2, we develop a model of export choice and marketing costs. In section 3, we describe the Uganda household survey and we introduce our marketing costs hypothesis. In section 4, we explain the empirical strategy and discuss results. In Section 5, we provide robustness checks and sensitivity analysis. Section 6 concludes.

\section{A Model of Marketing Costs and Exports}

We begin by laying out a simple model of export crop participation with marketing costs. Farmers, who are endowed with one unit of land, must decide whether to specialize in the production of food crops or export crops. Specialization in export crops delivers a physical output of $A$ per unit of land. Farmers are heterogeneous in land quality, ability in crop husbandry, fixed assets and labor endowment. To capture this exogenous heterogeneity across farmers, we let output $A$ follow a density function $f$ with support $[0, \infty)$. In contrast, specialization in food crops has a homogeneous return of $R$ per unit of land. The relative price of export crops to food crops is denoted by $p$.

Food crops and export crops differ in their marketability. Food crops are used for own consumption or can be marketed at no cost. To simplify the analysis, we assume that there is a fringe of food producers that supply food crops at a constant marginal cost. These food producers are arbitrage food traders, landless individuals working on public land or farmers who cannot meet the fixed costs of export participation (in scale, know-how, etc.). This assumption allows us to pin down the price of food, which we thereby set to one. ${ }^{5}$

\footnotetext{
${ }^{5}$ The assumptions of complete specialization in production and of the existence of a fringe of food production at constant marginal cost simplify the model. In a different technological environment, with decreasing returns for instance, some farmers will end up in an interior solution with positive production of both food and export crops. This just complicates the computation of the expected export output without
} 
Marketing export crops is costly. We assume that export activities are carried out by intermediaries that purchase the export crop locally and sell it internationally. Farmers who choose to produce export crops need to transport and market their output to the local intermediaries, who are in turn in charge of shipping output to international markets.

The economy is composed of many districts. For simplicity, we assume that farmers need to sell their export crop output to an intermediary in their own district. A district is represented by a unit circle. Farmers are uniformly distributed along the circle with a measure of $L$ farmers at each point in the circle. There is a finite number of intermediaries, $n$, who are located symmetrically along the same circle, at a distance of $1 / n$ from each other. The distance between farmers and intermediaries determines the marketing (transport) costs. A farmer that is located at a distance $x$ from a given intermediary incurs a marketing cost of $\delta x$ per unit of output.

Intermediaries have market power and compete in prices. Farmers are small and take prices from the different intermediaries as given. Once farmers get a draw $A$ from $f$, they make two decisions: (1) whether to produce food or export crops; (2) to which intermediary to sell the output of the export crop. The decision sequence is solved backwards. First, each farmer finds the intermediary $i$ that offers him the best "price-distance" combination, i.e., the maximum net price $\left(p_{i}-\delta x_{i}\right)$. Let $(p, x)$ denote the best price-distance combination for a given farmer. Given $(p, x)$ and the output level $A$, the farmer chooses to produce export crops or food crops. Farmers with $(p-\delta x) A \geq R$ specialize in export crops, while farmers with $(p-\delta x) A<R$ specialize in food crops. We can thus define an export specialization cutoff $\widetilde{A}$, the level of output that leaves a farmer indifferent between cropping activities, given by $(p-\delta x) \widetilde{A}(p, x)=R$.

Expected supply of export crops at a price-distance combination $(p, x)$ is obtained by

adding further insights. On the other hand, in the absence of the fringe food production, the expansion of export cropping may cause food supply to decline and food price to increase. This will prevent some farmers at the margin from specializing in exports. While these dynamics seem interesting to explore, our qualitative conclusion from the model - that lower trading costs lead to more export participation and lower poverty - are not affected by them. 
integrating over the potential returns above the cutoff $\widetilde{A}$,

$$
q(p, x)= \begin{cases}L \int_{\widetilde{A}(p, x)}^{\infty} A f(A) d A ; & p-\delta x>0 \\ 0 & p-\delta x \leq 0\end{cases}
$$

Intermediaries buy export crops from farmers at the price $p$, and sell the crops in international markets at the exogenous international price, $P^{*}$. The cost of transporting crops from a district to the international market is given by

(2) $C=D+d Q$,

where $D$ is a fixed cost of intermediation, $Q$ is the total quantity of export crops that an intermediary buys from all farmers, and $d$ is the unitary transport cost to ship output from the center of the district (given by the center of the circle) to international markets. Surplus is given by $\left(P^{*}-d-p\right) Q-D$. There is free entry until profits from the intermediation activity are zero. The location choice is exogenous.

A given intermediary $i$ chooses a price $p_{i}$ taking competition as given. Since intermediaries are symmetric, they charge the same price in equilibrium. We can thus summarize the competition faced by intermediary $i$ by the price charged by his competitors, $p_{0}$, and by the total number of competitors in a district, $n$. The problem of intermediary $i$ is

$$
\max _{p_{i}}\left(P^{*}-d-p_{i}\right) Q\left(p_{i}, p_{0}, n\right)-D
$$

To solve the maximization problem, we need to construct the total supply faced by intermediary $i, Q\left(p_{i}, p_{0}, n\right)$. Because of the symmetry in prices, we only need to consider the two contiguous competitors, which are located at a distance of $1 / n$ to the left and to the right of $i$. Let $x$ denote the distance between intermediary $i$ and a farmer located to his right. This farmer is located at a distance $1 / n-x$ from the right competitor. Given the prices charged by $i$ and by the right competitor, $p_{i}$ and $p_{0}$, we can define a cutoff distance $\widetilde{x}$ so that the farmer located at $\widetilde{x}$ is indifferent between the two intermediaries. The cutoff 
distance is defined by $p_{i}-\delta \widetilde{x}\left(p_{i}, p_{0}, n\right)=p_{0}-\delta\left(\frac{1}{n}-\widetilde{x}\left(p_{i}, p_{0}, n\right)\right)$; with

(4) $\widetilde{x}\left(p_{i}, p_{0}, n\right)=\frac{1}{2 n}+\frac{p_{i}-p_{0}}{2 \delta}$.

Farmers at a distance $x \leq \widetilde{x}\left(p_{i}, p_{0}, n\right)$ sell to intermediary $i$ and farmers at a distance $x>\widetilde{x}\left(p_{i}, p_{0}, n\right)$ sell to the right competitor.

Total supply faced by an intermediary $i$ from farmers located to the right and to the left is obtained by integrating the expected supply defined in (1) over farmers at distances between zero and $\widetilde{x}$. This yields

$$
Q\left(p_{i}, p_{0}, n\right)=2 \int_{0}^{\widetilde{x}\left(p_{i}, p_{0}, n\right)} q\left(p_{i}, x\right) d x
$$

The situation is depicted in Figure 1. The base and height of the rectangle represent the two dimensions of heterogeneity among farmers: location and potential output from export crops. Distance to intermediary $i$ is measured in the horizontal axis, with the largest possible distance being $1 / n$, and output on the vertical axis. Prices are given. Farmers to the right of $\widetilde{x}$ choose the competitor's price-distance combination (although some of them might end up choosing to specialize in food crops). Farmers to the left of $\widetilde{x}$ choose the price-distance combination offered by intermediary $i$. Among the latter, those farmers with lower potential output from export crops $(A<\widetilde{A})$ specialize in food crops, and those with higher potential output $(A \geq \widetilde{A})$ specialize in export crops and constitute the supply faced by intermediary $i$. The cutoff output level $\widetilde{A}$ depends on distance. Farmers that are closer to the intermediary need to cover lower transportation costs, therefore, they require a lower level of output to find export crops more profitable than food crops.

Intermediaries choose prices to maximize profits defined in (3) taking the prices of the competitors as given and subject to the supply function defined in (5). In equilibrium all intermediaries charge the same price. For a given number of intermediaries $n$, the profit maximizing first order condition evaluated at equilibrium prices $p$ is (dropping subindex $i$ )

(6) $-\left.Q\left(p, p_{0}, n\right)\right|_{p_{0}=p}+\left.\left(P^{*}-d-p\right) \frac{\partial Q\left(p, p_{0}, n\right)}{\partial p}\right|_{p_{0}=p}=0$. 
The number of intermediaries $n$ is determined endogenously by the free-entry, zero-profit condition. This is

$$
\left.\left(P^{*}-d-p\right) Q\left(p, p_{0}, n\right)\right|_{p_{0}=p}-D=0 .
$$

Equations (6) and (7), subject to the supply function in (5), define the equilibrium prices $p$ and number of competitors $n$.

To characterize the equilibrium, we need to impose some structure on the density function of export crop yields. In Figure 2, we explore the case of an exponential distribution of $A$. The combinations of prices and number of intermediaries that satisfy the profit maximization condition (6) are positively sloped. More intermediaries $n$ means more competition so that the profit maximizing price offered to farmers is higher. The combination of prices and intermediaries that satisfy the zero profit condition (7) is negatively sloped. Lower prices offered to farmers mean higher profits so that more intermediaries can afford to pay the fixed costs and enter the market. The equilibrium prices and number of competitors are given by the intersection point $E{ }^{6}$

The model delivers several predictions that we test in sections 4 and 5 . Our main hypothesis is that households residing in districts with a larger number of intermediaries, and thus with lower marketing costs for export crops, are less likely to be poor; that the choice to produce export crops is in part explained by the presence of intermediaries; and that the choice to produce export crops in part explains the lower likelihood of poverty. In the model, we can establish these results by comparing two districts with different number of intermediaries. ${ }^{7}$ Given the equilibrium symmetric price offered by all intermediaries and the number of intermediaries, the probability that a farmer located at $x$ specializes in export crops is $1-F(\widetilde{A}(x, p))$; hence, the probability that a random farmer, anywhere in the circle,

\footnotetext{
${ }^{6}$ Similar equilibria can be found for other functions $f$ such as the Pareto distribution (which is often used in productivity analysis). Notice that an equilibrium with entry may not exist (for example in the case of a low international price $P^{*}$ and large costs of access to international markets $D$ and $d$ ). See below.

${ }^{7}$ Notice that these are cross-sectional correlations (across districts) and not comparative static results because $n$ is an endogenous variable (see below for a discussion of some exogenous variables that determine $p$ and $n$ in equilibrium). In fact, this analysis highlights the endogeneity issues that we tackle in our empirical work.
} 
produces export crops can be derived after integration over $x$

(8) $\pi(p, n)=2 n \int_{0}^{\frac{1}{2 n}}[1-F(\widetilde{A}(x, p))] d x$.

In Appendix A, we show that, conditional on the price $p$, this probability is increasing in the number of intermediaries $n$. This is because the presence of more intermediaries reduces the average distance from farmers to intermediaries and thus decreases average marketing costs. In consequence, a larger number of farmers will find it profitable to specialize in export crops. Further, this implies that the expected income of the farmer increases in $n$ and thus that poverty declines with $n$. The expected income of a farmer at $x$ is $F(\widetilde{A}(x, p)) R+p \frac{q(x, p)}{L}$, where $q(x, p) / L$ is the expected output of export crops by a typical farmers (equation (1)). Integrating over $x$, the expected income of a random farmer is

(9) $Y(p, n)=2 n \int_{0}^{\frac{1}{2 n}}\left[F(\widetilde{A}(x, p)) R+p \frac{q(x, p)}{L}\right] d x$.

We prove in Appendix A that $Y(\cdot)$ is indeed increasing in $n$. For our purposes, these results establish a relationship between lower marketing costs in export cropping and lower poverty in rural areas.

In our empirical work, we will exploit regional variation in the number of intermediaries to explore the relationship between export marketing costs, export adoption, and poverty. The model can be used to think about exogenous determinants of the equilibrium number of intermediaries. Both $p$ and $n$ depend on parameters that are common to all districts, like the international price $\left(P^{*}\right)$, and parameters that can vary across districts, like the out-of-district cost of access to international markets $(D$ and $d)$, district size $(L)$, and the distribution of returns to export cropping. Therefore, differences in these parameters across districts will generate differences in prices and in the number of intermediaries. For practical purposes, this implies that we can use some of these exogenous parameters, such as the out-of-district cost of transportation to international markets, ${ }^{8}$ as valid instruments in the instrumental variables specifications of the model (sections 4 and 5).

\footnotetext{
${ }^{8}$ This is an out-of-district cost and must not be confused with marketing costs within a district.
} 
We close the discussion of our model with two remarks. First, crop marketing between intermediaries and farmers in developing countries is often subject to incomplete contracts (Ashraf, Giné and Karlan, 2008; Brambilla and Porto, 2007; Kranton and Swamy, 2008). With limited contract enforceability, intermediaries, especially if there are only a few, can hold up farmers paying low prices for their crops. This can lead to a situation where few intermediaries enter and few farmers adopt. In our model there are two main reasons why a high market density can facilitate the adoption of export crops and lower poverty: lower marketing costs within a district and higher offered prices. Thus, while we do not model hold-up issues explicitly, in the sense that we do not model the role of incomplete contracts as in Kranton and Swamy (2008), we do describe a setting in which profit maximization by intermediaries with market power leads to price levels that prevent some farmers from adopting export crops, which in turn also leads to low market density. In our model, market density is determined by out-of-district transportation costs, district size and productivity parameters. But hold up and incomplete contracting are other possible determinants and our story is entirely consistent with them.

Second, the interrelation between marketing costs and export opportunities in poverty reduction is a feature of the model that deserves emphasis. The claims in this paper are that exports matter for poverty alleviation provided marketing costs are low enough, and that low marketing costs are not necessarily conducive to poverty alleviation in the absence of export opportunities. It is the combination of export opportunities (for example, through a high international price) and domestic conditions (through low marketing costs) that works. To see this, notice that, for given intermediation costs, a sufficiently low international price can cause the Profit Maximization and the Zero Profit loci not to cross in the positive orthant. Similarly, even if the international price is high, prohibitive marketing costs can lead to an autarky equilibrium with farmers specialized in low-return food crops. In this situation, high marketing costs prevent farmers from realizing the gains from exports. 


\section{The Uganda National Household Survey}

To test the relationship between marketing costs, export cropping, and poverty, we work with the 1999/2000 Uganda National Household Survey (UNHS). The data are a large-scale household survey conducted by the Uganda Bureau of Statistics that covers the entire country, rural and urban areas. The sampling design is a stratified two-stage sampling. The first stage units are the Enumerator Areas of the 1991 Population Census and the second stage units are the households.

There are two sets of data in the UNHS: household data and community data. From the household data we construct measures of expenditures, poverty and export participation at the household level. With the community data, we construct a measure of marketing costs at the district level.

The household-level data include socio-economic and enterprise modules. There are modules related to household characteristics (household composition, demographics), activity status, health, education, and housing amenities. There are also questions on consumption expenditure and sources of income (farm and non-farm activities, employment, remittances), and a crop module with questions on land allocation, production, sales, home-consumption, etc. Sample statistics are reported in Table 1.

Our empirical analysis focuses on poverty and household expenditures. To determine the poverty status of each household, we use the expenditure module and compare household expenditures with poverty lines. We use the head count as a measure of poverty: a household with a per equivalent adult expenditure below the poverty line is considered poor. ${ }^{9}$ Average per equivalent adult expenditure in rural Uganda was 42.64 PPP dollars per month $(29,550$ Uganda Shillings). Rural poverty lines for each province were constructed by Appleton (1999). The average poverty line for rural areas was 31.44 PPP dollars per month $(21,790$ Ugandan Shillings), or 1.05 dollars per day. The poverty rate in 1999 was 35 percent.

Households do not export directly but we can infer their export-related activities from the crops they grow. We divide crops into two groups, export crops and food crops. The

\footnotetext{
${ }^{9}$ Per equivalent adult expenditure is a measure of per capita expenditure that accounts for economies of scale and for differences in the consumption needs across demographic categories (children, adults, etc.) within the household.
} 
division is based on aggregate data on Ugandan exports, reported in Table 2. Major export commodities are coffee, cotton, tea, and tobacco, and other non-traditional products such as fish, fruits, and flowers. In the crop questionnaire of the Uganda National Household Survey, prevailing export crops are coffee, tea, cotton, pineapples, and passion fruits. ${ }^{10}$ Food crops include matooke (banana), maize, sweet potatoes, sorghum. Food crops are mostly destined to home consumption.

In our analysis, we aggregate all the export crops into one export crop activity. While there may be differences across crops that are worth exploring, our data are not rich enough to conduct a detailed disaggregated analysis (see below). In the empirical work, we exploit regional disparities in export adoption, poverty, and marketing costs as identifying variation. Figure 3 gives an overview of regional disparities in export crops in Uganda based on information from the UNHS and FAO. The figure includes four panels, each one of them depicting the prevalence of different crops in different regions. The top-left map reveals that coffee is mostly produced in the center of the country and in mountainous regions in the Southwest, West, Northwest, and East. Tea (top-right map) is produced in the South, the Center, and in some Northern regions. Cotton (bottom-left panel) is the major crop of the Northern provinces; there is some cotton production in the Southwest and Southeast as well. Finally, fruits, like passion fruits and pineapples, are grown in the Center, the Northwest and the Southwest.

To quantify export participation at the household level, we use two definitions, the share of land allocated to export crops and the share of income derived from export crops. The average plot size in the data was 2.57 acres (Table 1). Around 7 percent of household land is allocated to export crops; around 8 percent of household income is derived from the sale of these crops. Participation in export agriculture is in fact limited in Uganda. It is our aim to explore to what extent this is due to high export marketing costs.

Our measure of marketing costs in export agriculture comes from the community module. The community module collects information on community characteristics at the level of enumerator areas (the first stage sampling units). In our regression analysis, we use this

\footnotetext{
${ }^{10}$ Other export products, like vanilla, fish or flowers, are not significant in the 1999/2000 data.
} 
information aggregated at the district level. We focus our analysis on rural areas, where agriculture accounts for a large share of household income and the production of export crops is more meaningful. ${ }^{11}$

As suggested by the model of section 2, marketing costs are closely related to the extent of intermediation activity given by the presence of outlets where farmers can sell their export crops. There are three different types of such markets in rural Uganda. ${ }^{12}$ First, the most widespread way of marketing export crops is through export intermediaries. These are agents that purchase output from farmers, store the production and then transport the agricultural produce with pick-ups or small trucks to Kampala, the capital of Uganda. Second, typical outlets for cash crop are district markets or stalls along the road to Kampala. Third, an additional channel to sell agricultural produce is through large commercial plantations, particularly of coffee and tea. These plantations often purchase the output of neighbor farmers thereby constituting additional channels of market availability. Most plantations are run by foreign firms.

The community module provides information on whether there is at least one of the three types of outlets available in each community. ${ }^{13}$ Since communities are very small and farmers can in principle easily commercialize their products in neighboring communities, we construct a measure of market density at the district level. There are several communities (enumerator areas) in each district, and in each community the availability of markets is a dichotomous variable. We define export market density as the fraction of communities in a given district in which there is at least one market for export crops available. Market density captures the extent of intermediation activity in a district (including intermediaries in the strict sense, road markets, and plantations). In districts where market density is higher, it is easier for farmers to commercialize their export crops and marketing costs are lower.

\footnotetext{
${ }^{11}$ In urban areas, households earn a significant share of income from wage labor, odd jobs and self employment, whereas agricultural income is much less important.

${ }^{12}$ The survey asks separate questions on availability of food markets where farmers can sell the production surplus of food crops. This means that the availability of agricultural export produce markets refers to commodity markets and cash crops like coffee, tea, and cotton.

${ }^{13}$ There is no information on the specific type of outlet or on the number of outlets. This forces us to aggregate export market availability for all crops and prevents us from exploiting differences in intermediation costs at the crop level.
} 
At the national level, the average market density is 0.37 (Table 3). This means that, on average, in 37 percent of the communities there is at least one outlet for agricultural produce, namely intermediaries, export crop stalls, or local large plantations. Instead, the prevalence of surplus food markets (sweet potatoes, bananas, tomatoes) is much higher: average food market density reaches 0.76 .

Table 3 reports other important measures of community infrastructure that we use in our regression analysis. In the community module, there are questions on distance to paved roads; dichotomous access to infrastructure variables such as access to credit, improved seeds, oxen use and rental, tractors, extension services; major village constraints in terms of input markets, roads, disease, security, land, credit, land fertility; and indicators of access to veterinary services, existence of land conflict, availability of communal land, primary school, free medicine, water services, public hospital, and private hospitals. We use all these control variables in the regression estimation.

\section{Estimation and Results}

Our testing hypothesis is that a farmer faced with the decision to adopt a higher-return export crop is more likely to participate, therefore being less likely to be poor, when access to export markets is less costly. This is because better access to export markets facilitates trade and lowers marketing costs. In our analysis, we use market density as a measure of access to export markets at the district level.

Figure 4 takes a first look at the data to establish descriptive correlations between the three variables of interest, market density, exports and poverty, using non-parametric models. For each pair of variables, we estimate Fan locally kernel weighted regressions with a Gaussian kernel. ${ }^{14}$ The first panel plots the estimates of a non-parametric regression between poverty and market density. We see that the relationship is negative, with lower poverty associated with higher market density. Notice that the relationship is quite strong when there are few

\footnotetext{
${ }^{14}$ The Fan regression comprises a set of weighted local OLS regressions at different levels of the right-hand side variable $x$. For a given level of $x$, observations further away are given less weight according to the Gaussian function and the bandwidth (equal to 0.15 in the first and second panels and 0.05 in the third panel). See Pagan and Ullah (1999) for further details.
} 
markets available but debilitates at high market density.

The second panel displays the non-parametric correlation between export market density and export crop participation. The solid line corresponds to the share of land allocated to export crops and the broken line, to the share of export crops in income. As our hypothesis suggests, the graph reveals that the availability of markets for agriculture produce is positively linked to export cropping. Finally, the third panel displays the relationship between poverty and export crop participation. As argued, the graph reveals that a higher participation in export agriculture is associated with a lower likelihood of poverty.

The graphical representation of the relationship between market density, export cropping, and poverty is a descriptive tool. In what follows, we approach the issue from a formal regression analysis of each of the three correlations illustrated in Figure 4. The econometric model takes other controls and reverse causality issues into account.

\subsection{An Econometric Model of Market Density and Poverty}

We begin by investigating the relationship between poverty and export marketing costs, which are inversely related to export market density. We set up the following regression model

$$
P_{h c}=\alpha_{1} M_{c}+\gamma_{1} p r_{c}+\mathbf{x}_{h c}^{\prime} \beta_{1}+\mathbf{z}_{c}^{\prime} \delta_{1}+\epsilon_{h c}^{1}
$$

where $P_{h c}$ is a dichotomous variable that indicates the poverty status of household $h$ in district $c, M_{c}$ is export market density in district $c, p r_{c}$ is an export price index in district $c$, and $\mathbf{x}_{h c}$ and $\mathbf{z}_{c}$ are household and district characteristics. Market density captures the three marketing channels described in the previous section: i) intermediaries; ii) export crop market stalls; iii) large scale plantations. Estimates of $\alpha_{1}$ will reveal how poverty is affected by marketing costs in exports.

The model includes a large set of controls. The vector $\mathbf{x}_{h c}$ includes household characteristics: size, demographic composition, age and gender of the household head, the level of education and literacy of the head, and his/her health status. We also include 
a full set of district variables, $\mathbf{z}_{c}$, that measure social and economic infrastructure. The district controls are the variables described in Table 3. They include access to credit, roads, equipment (oxen, tractors), inputs, and extension services, indicators of major agricultural constraints (land quality, land availability, input availability, diseases), educational, medical, sanitary and veterinary infrastructure, and prevalence of security and conflicts. This extensive set of district controls is important to purge the regression from district effects that may confound the effects of export market density. For instance, the district controls account for differences in district economic (roads, equipment, credit) and social (health) infrastructure that can simultaneously affect the level of poverty, export crop adoption and market density. Similarly, these variables will control for social conflict and security, which might be conducive to higher poverty and lower export participation. This is especially important in some parts of Northern Uganda. ${ }^{15}$ Further, they account for potential bio-climatic differences in the country by controlling for differences in input availability (land, variable inputs) and the average quality of land. In our model, all these district controls (or, rather, their linear combination) work as a proxy for the district effect (the district component of the error term in equation (10)). In the absence of panel data, including this proxy improves the estimation of the market density term $\alpha_{1}$. However, being just proxies, the estimates of the district controls lack any structural interpretation.

An important control in our regression is the export price index, which serves several purposes. As described in the model of section 2, differences in intermediation activity across districts (i.e., differences in market density) are associated with differences in export marketing costs and with differences in the prices offered to the farmers. Market density is an imperfect measure of marketing costs in exports and could include traces of price effects. It is thus important to control for prices to isolate the true effects of marketing costs on poverty.

To construct the price index, we proceed as follows. Households that produce export crops report unit values for their sales, which approximate the producer prices net of marketing costs $(p-\delta x$ in the model of Section 2$)$. Given the price $p$ offered by the

\footnotetext{
${ }^{15}$ Other Northern districts, where conflict is more widespread, are excluded from the regressions.
} 
intermediaries, differences in unit values across households within a district are explained mostly by marketing costs, $\delta x .{ }^{16}$ Since we want to separate the effect of prices from the effects of export marketing costs, we need to control for the price offered by the intermediaries in a district, $p$ (and not for the reported $p-\delta x$, which varies at the household level). To do this, we approximate the price $p$ with the price faced by the farmer with the lowest possible marketing cost ( $x=0$ in the model), that is, the farmer with the highest observed unit value. For robustness against outliers, we use the 75th percentile of the distribution of household unit values in each district as a measure of $p$. Finally, since we are pooling together different export crops (coffee, cotton, tea, passion fruits and pineapples), the export price index is a weighted average of the 75th percentile log unit values of each of these crops, with weights given by the average share of land allocated to each crop in the district.

Notice that export prices and the weights attached to them play another important function. As shown in Figure 3, farmers in different regions tend to specialize in different export crops. Since these crops sell at different prices, specialization in different export crops can lead to different poverty impacts. These regional differences in profitability across export crops can be controlled for with the weights used in the construction of the export price, that is, the shares of each export crop.

Even after controlling for all these confounding factors, the major econometric concern with regression (10) is the reverse causality between poverty and market density. Poverty is lower when marking costs are lower, and markets may develop in richer districts. We need instruments that are exogenous determinants of market density and that vary by district. The model of section 2 suggests that good candidates are the costs of intermediation activity, such as the out-of-district transportation cost from each district to international markets, represented in the model by $d$ and $D$. Out-of-district transportation costs indicate

\footnotetext{
${ }^{16}$ The argument that differences in unit values at the household level are mostly explained by marketing costs is clearly an abstraction of the model. In practice, part of those differences can be explained by differences in market power at the farm level. Following a suggestion of one of the referees, we tested the notion that marketing costs do indeed account for those differences by running regressions, pooling all crops, of $\log$ unit values (as deviations from district means) on the indicator of export market availability at the village level (controlling also for district fixed effects). We found a positive and statistically significant association between these variables. It follows that, within a district, farmers closer to the market fetch higher unit values, which is in line with our empirical strategy.
} 
how difficult it is for intermediaries to reach export destinations. It is a fundamental determinant of the profitability of intermediation activities in export crops, either in the form of intermediaries in the strict sense, market stalls, or plantations, and thus a determinant of market density, our endogenous variable.

In Uganda, a landlocked country, most international shipments must go through the capital, Kampala. We proxy the out-of-district transportation costs with district level data on transportation costs from the center of each district to Kampala. These costs are reported in the community questionnaire of the Uganda National Household Survey as the monetary cost of reaching Kampala by car/truck. ${ }^{17}$

This strategy requires a careful control of the regression so as to make sure that out-of-district transportation costs do not have a direct effect on the left-hand side variable (poverty). In our regression model, there are two sets of such controls. A major control is the export price index. Under imperfect competition among intermediaries, out-of-district transportation costs are borne both by intermediaries (directly) and by farmers (via lower prices). In districts where out-of-district transportation costs are lower, the profits of intermediation are higher, more intermediaries enter, and farmers enjoy higher prices and are less likely to be poor. For the instrument to satisfy the exclusion restriction, we need to control for the fraction of the out-of-district transportation costs that are borne by farmers. We achieve this by including the export price index, which summarizes farmer prices and includes the pass-through of out-of-district transportation costs. After including the price index, there is no direct effect of out-of-district transportation costs on poverty via cost pass-through.

The other set of controls comprises all district characteristics that could be affected by out-of-district transport costs and that could have an effect on poverty. Districts with lower out-of-district transport costs to Kampala could be less poor due to improved infrastructure, higher local development, and better institutional quality. This effect is also already controlled for in regression (10) with the extensive set of districts characteristics

\footnotetext{
${ }^{17}$ In this section, we estimate the model using one instrumental variable for our endogenous regressor. In section 5 , we provide a sensitivity analysis by estimating the model with an additional instrument.
} 
included in z. ${ }^{18}$ After including producer prices and district characteristics in the model, all the channels through which out-of-district transport costs could affect poverty are accounted for.

As a robustness check, we also include an additional district control, the density of food markets, defined analogously to export market density. These markets are less sophisticated than agriculture produce markets (coffee stalls, intermediaries and plantations) and are thus more ordinary. This variable controls for the thickness of food markets (and thus accounts for food risk). In fact, in Uganda, food markets are fairly common whenever there are paved or tarred roads. Food market density is a good aggregate indicator of district infrastructure and development and could capture additional unobserved district characteristics.

The main results are shown in Table 4. In the first panel, we report estimates from linear IV regressions. The first column corresponds to a simple linear model that only includes households characteristics $\mathbf{x}_{h c}$ as controls. We find that market density, $M_{c}$, is negatively and significantly associated with poverty $\left(\widehat{\alpha}_{1}=-0.56\right)$. Since $M_{c}$ varies at the district level, the estimation of the variance is corrected for clustering effects.

In column (2) of Table 4, we add district characteristics and infrastructure variables, $\mathbf{z}_{c}$, and the export crop price index, $p r_{c}$ (Table A1 in Appendix B reports these estimates). The negative association between export market density and poverty is robust to the inclusion of these variables. Notice, however, that the addition of district variables has a sizeable impact on the coefficient of market density, which drops to -0.27 .

In column (3), we include food market density as an additional district variable to control for further unobserved district effects. We find that poverty is negatively associated with the presence of food markets, although the relationship is not as strong as expected. For our purposes, however, the critical finding is that the negative association between food market density and poverty still shows up strongly in the regressions; further, the magnitude of $\alpha_{1}$, -0.28 , does not change much with respect to Model 2 (which is additional evidence that the variables $\mathbf{z}$ account for much of the district effects in the model). Our findings support the hypothesis that households residing in districts endowed with more agriculture export

\footnotetext{
${ }^{18}$ These include access variables (to credit, roads, equipment, inputs, and extension services), agricultural constraints (land quality, land availability), social infrastructure (education, health), security and conflicts.
} 
markets are, on average, less likely to be poor: increasing the density of export markets by 5 percentage points (from an average market density of 0.37 - see Table 3 ) would cause poverty to decline by 1.4 percentage points.

The validity of these results depends to a larger extent on the quality of the instrument. We can assess how good our instrument is by looking at the first stage regression, whereby we regress the endogenous variable, market density, on the out-of-district transportation costs, household characteristics $\mathbf{x}_{h c}$, district level controls $\mathbf{z}_{c}$, the export price index, and food markets (explanatory variables vary across columns as described above). We report the main coefficients at the bottom of the first row panel in Table 4 . Notice that our instrument has good explanatory power in the first stage regression: districts with lower transportation costs to Kampala are endowed with more export markets. Further, the $F$-statistic is greater than 10 in the three specifications, thus passing the test of weak instruments proposed by Stock and Staiger (1997). Finally, the abrupt changes in the model when adding the district controls and its stability when moving from Model 2 to Model 3 suggest that the district effects are accounted for, a requirement for consistency of the IV estimator. Notice, however, that in these regressions exogeneity of the instruments has to be maintained and cannot be tested. In section 5, we expand the set of instruments as part of our robustness checks and we perform overidentification tests of the model.

In the second panel of Table 4, we report OLS results, which, as expected, are negative (and statistically significant): in Models 2 and 3, for instance, the OLS estimates are -0.12 and -0.11 , respectively. In our context, IV and OLS can differ because of two main reasons: endogeneity bias (as argued above) and attenuation bias due to measurement error. Market density is measured with error because, as revealed by our own field work in Uganda, there were differences in the interpretation of the community questions on the availability of export outlets. In some cases, the confusion arose because the questions referred to cash crops but did not include a full list of those crops. In other cases, there were discrepancies among respondents about specific outlets (for example, whether a matooke truck could also work as a coffee truck intermediary) or about the periodicity of markets (daily as opposed to occasional stalls or truck presence). While attenuation bias would cause OLS to be smaller 
than IV, the endogeneity bias (such that higher poverty correlates with lower market density) would produce larger IV estimates instead. As in many other cases in the literature, our results suggest that attenuation bias is strong and dominates the endogeneity bias. There are numerous similar examples in the literature on the returns to schooling (Card, 1999), institutions (Acemoglu, Johnson, and Robinson, 2001), and trade (Frankel and Romer, 1999). To further support the argument that attenuation bias is strong, we run, as in Acemoglu et al. (2001), an IV regression using a measure of overall market availability (agricultural goods, food, inputs, consumer goods) as a pseudo-instrument for export market density. This pseudo-instrument would fix the attenuation bias but would not fix the endogeneity bias (because overall market availability is endogenous itself). In these IV models, the estimates are $-0.89(0.36)^{* * *},-0.31(0.14)^{* *}$, and $-0.29(0.15)^{* *}$ for Models 1-3, respectively. These estimates are purged from the attenuation bias but are, nevertheless, close to our consistent IV estimate, thus suggesting that measurement error causes an attenuation bias of the right order of magnitude. While this strategy does not provide a formal test of attenuation bias vis-à-vis endogeneity bias, it gives a sense of their relative magnitudes. As in Acemoglu, Johnson, and Robinson (2001), attenuation bias can indeed be quite strong.

Since the poverty indicator $P$ is a dichotomous variable, we set up Probit models of poverty with endogenous regressors in addition to the linear models described above. We work with a control function approach, which requires the inclusion of the residuals from the first stage regression, together with the endogenous variable, in the second stage regression (Newey, 1987; Blundell and Powell, 2004). Results are reported in the third panel of Table 4. Our finding, that export market density is conducive to poverty reduction, is robust to the Probit specification. The magnitudes of the marginal effects, equal to -0.35 in Model 3, are slightly higher, but comparable, to the linear case.

The last panel of Table 4 reports results where the dependent variable is the log of per equivalent adult expenditure (the measure of household wellbeing that is used to compute the poverty count). As expected, we find a strong positive association between household expenditures and the availability of export markets. In Models 2 and 3, an increase in export market density of 5 percentage points would cause the per equivalent adult expenditure of a 
typical Ugandan household to increase by 3.65 percentage points. While our main interest is in poverty impacts, this result shows that the availability of export markets can bring about benefits for all households in Uganda, not only for poorer ones.

\subsection{The Exports Channel}

We have established a causal relationship between marketing costs, as measured by market density, and poverty. In this section we show that the adoption of export crops is an important channel that explains this relationship: when marketing costs are lower, households find it profitable to reallocate some resources from the production of home consumption crops to higher-yield export crops. We first show that export crops become more prevalent when market density is higher; and later show that growing export crops does indeed substantially help reduce poverty at the household level.

We begin by estimating the following regression model

$$
s_{h c}=\alpha_{2} M_{c}+\gamma_{2} p r_{c}+\mathbf{x}_{h c}^{s \prime} \beta_{2}+\mathbf{z}_{c}^{\prime} \delta_{2}+\epsilon_{h c}^{2}
$$

where $s_{h c}$ is the measure of export participation, defined as the share of land allocated to export crops and, alternatively, as the share of income derived from export crops, $M_{c}$ is market density, $p r_{c}$ is the export crop price index, $\mathbf{x}_{h c}^{s}$ are household controls, and $\mathbf{z}_{c}$ are district controls. ${ }^{19}$

As in the poverty model (10), market density may be endogenous to participation in export markets. That is, more markets may develop in those districts where farmers are more likely to grow export crops. To account for this, we use the out-of-district transportation cost to international markets, measured as the cost of transportation to Kampala, as instrument

\footnotetext{
${ }^{19}$ It is important to look at both dependent variables - share of land and share of income - since they reveal different aspects of the decision to produce for exports. Land allocation is the most straightforward indicator of participation because it measures the allocation of household capital to alternative uses. A problem with measures of land allocation is that, depending on the crop, it may respond slowly to changes in the independent variables. This is the case, for example, with tree crops like coffee or tea. In these instances, it may be difficult for farmers to switch from tree crops to food crops (or vice versa) after a change in contemporaneous variables. However, farmers can adjust other inputs, like effort or fertilizer. If coffee prices are low, for instance, farmers may prefer to keep the trees but put less effort or apply less fertilizer. A better measure to account for these effects is thus the share of income generated by the export crops.
} 
for $M_{c}{ }^{20}$

We adopt the same three specifications as in (10) and report results in Table 5. Column (1) corresponds to the simple model with only household controls. In column (2), we add the measures of district infrastructure and other observed characteristics, as well as the export price index, to control for confounding community effects; in column (3) we add food market density as a control. We find very strong evidence that a higher export market density induces farmers to participate more in export agriculture. This result holds for all specifications. It also holds for our alternative measure of export cropping, namely the share of income derived from them-see Table 6. This is an important result: improved trade facilitation and lower export marketing costs matter for export crop participation. The point estimate is $\widehat{\alpha}_{2}=0.18$; an increase in export market density of 5 percentage points would cause the average land share devoted to export crops to increase by 0.9 percentage points, equivalent to 13 percent of the average export participation (around 7 percent in Table 1).

Since our two measures of export participation are shares that are left censored at 0 and right censored at 1, we estimate Tobit models with a control function approach (to account for the endogeneity of export market availability). As before, this requires that we include the estimated residuals from the first stage regression along with the endogenous variable and the other exogenous regressors in a standard Tobit model. In the second panel of Table 5, we show that our findings are robust to censoring of the export participation variables. The coefficients on market density are positive and highly significant. Furthermore, the marginal effects of the Tobit estimates (the change in the unconditional average land share) is 0.18 , the same as the IV estimate in the first panel.

Table 6 reproduces the structure of Table 5 but uses the alternative definition of export crop participation, the share of income derived from cotton, tea, coffee, pineapples and passion fruit. Our findings are robust to this definition.

We turn now to the last link in our hypothesis: whether, at the household level, the adoption of export crops is associated with lower probability of poverty (and to a higher

\footnotetext{
${ }^{20}$ See Section 5 for results with an additional instrument.
} 
level of expenditure). The regression model is

$$
P_{h c}=\alpha_{3} s_{h c}+\gamma_{3} p r_{c}+\mathbf{x}_{h c}^{\prime} \beta_{3}+\mathbf{z}_{c}^{\prime} \delta_{3}+\epsilon_{h c}^{3}
$$

where, as before, $P_{h c}$ is a dichotomous variable indicating poverty and $s_{h c}$ is participation in export activities (measured by share of land or share of income). Both variables are defined at the household level. We are mostly interested in estimates of $\alpha_{3}$, the coefficient of export participation. Notice that participation in export cropping may be endogenous to the poverty status if, for instance, richer households are able to finance any start-up investments needed to enter export markets. Also, richer households may have more educated heads, who may be more productive in export crops. Our previous results suggest possible instruments for export cropping, namely the out-of-district cost of transportation to Kampala. ${ }^{21}$

Table 7 shows the results from instrumental variable regressions for the two definitions of export participation, the share of land and the share of income. The first three columns correspond to models of land shares, and the last three, to models of income shares. In the first row, we report results from linear IV models. In the second row, we report Probit models with endogenous regressors (using the control function method).

Overall, the relationship between these variables is negative: households involved in the production of export crops (like cotton, tea, coffee, fruits) are less likely to be poor than households that are not involved in export markets. We find that, indeed, lower marketing costs encourage export participation and lead to lower poverty. For instance, doubling export participation (from 7 percent land shares to 14 percent land shares) would reduce poverty by 13 percentage points (using the point estimates of the Probit marginal effects in Model 3 of the land shares).

In the last panel of Table 7, we report IV estimates of the relationship between export participation and per equivalent adult expenditures. As expected, this association is positive and statistically significant. The implication is that export participation not only reduces the

\footnotetext{
${ }^{21}$ It may be argued that this is not a good instrument because by using it as an instrument in equation (11) it satisfies the exclusion restriction and is thus not correlated with the shares $s_{h c}$. This is not correct. The instrument is, indeed, the predictions of $M$ from the first stage regression. In practice, in the linear model, this is the same as using out-of-district transportation costs directly in the IV estimation.
} 
likelihood of poverty but also increases the average level of expenditure of Ugandan farmers.

\subsection{Discussion}

While the focus of our work is on how export market density (including the presence of intermediaries, local markets and export crop plantations) fosters export agriculture and reduces poverty, other channels may also play a role. One of those channels is the provision of market information. Goyal (2008) shows that the implementation of e-Choupal, the introduction of warehouses and internet kiosks providing price information in rural India, caused soybean prices and land shares allocated to this crop to increase. Jensen (2007) shows how the adoption of mobile phones by South Indian fishermen reduced price dispersion, improved efficiency in the fisheries sector, and increased consumer and producer welfare in the region. In addition, other complementary factors may matter. For example, Ashraf, Giné and Karlan (2008) show that DrumNet, a project of PRIDE AFRICA to provide poor farmers with technical information, credit, and intermediation services, was initially successful in facilitating adoption of export crops and in increasing farm income. But the project collapsed later on due to low quality to meet European standards.

As explained in the model of section 2, there are two main reasons why a high market density can facilitate adoption and lower poverty: lower marketing costs within a district and higher offered prices. While in our model market density is determined by out-of-district transportation costs, district size or productivity parameters, more generally there might be other forces at play as well, especially hold up and incomplete contracting. With incomplete markets, hold up is very likely to arise, farmers end up receiving low price when there are few intermediaries, and few intermediaries thus enter. As a result, the adoption of export crops is hindered and poverty increases. This story is entirely consistent with our analysis. To see this, Figure 5 uncovers the strong positive association between the export crop market density and the export price index. It indeed suggests that higher market availability could lead to lower poverty via a price mechanism arising from more competition (and also from a lower likelihood of hold up) among intermediaries. However, this is not the channel that we 
emphasize in this paper which focuses instead on marketing costs in export crops. ${ }^{22}$ Since our approach only identifies the poverty impacts via lower marketing costs, our estimates provide a lower bound for the overall impacts of markets.

Our findings support the recent emphasis on the "aid for trade" approach to development policy which advocates poverty alleviation via aid aimed at expanding export opportunities and domestic complementarities to trade. To put our results into perspective we ask now about the potential for "aid for trade" as a vehicle for poverty reduction. Policymakers often need to choose among various interventions and it is useful to give a sense of the efficacy of this "aid for trade" strategy. In principle, we could use our regression results to compare the estimates of reductions in poverty due to increases in export market availability with the impacts of other social or infrastructure programs. This exercise is, however, of limited value for at least two reasons. First, social programs in health or education should be in place within the context of a broader development agenda, beyond poverty considerations alone. Second, as explained above, our estimation strategy is tailored to identify the impacts of export market density only and cannot thus identify the causal effect of the other controls in our regressions. Instead, we assess our estimates by comparing the impacts of export market availability with other trade related barriers, such as market access barriers in developed countries, tariff protection, and subsidies.

We propose to perform an experiment to calculate the increase in the export prices of agricultural products that would generate the same reduction in poverty as an increase in export market density of 5 percentage points. Although a full cost-benefit analysis of competing policies for poverty reduction is beyond the scope of this discussion, with an average market density of 0.37 and a standard deviation of 0.31 (see Table 3), an increase of $M_{c}$ of 0.05 seems plausible with a combination of increased incentives to FDI plantations, reductions in transport costs, or improvements in export productivity. Using the IV and IV-Probit estimates, poverty would decline by between 1.4 and 1.75 percentage points. Notice that farm-gate prices are kept constant in this exercise so that the decline in poverty

\footnotetext{
${ }^{22}$ See Kranton and Swamy (2008) for a model of hold up with one exporter and one local producer of textiles in India and Brambilla and Porto (2007) and Ashraf, Giné and Karlan (2008) for examples on Zambia and Kenya.
} 
due to the increase in market density takes places only via the reduction in marketing costs (within districts).

To compute the "export price change equivalent," we adopt (for simplicity) a scenario with only first order effects (that is, without supply responses). A first order change in the income generating equation of a typical farmer is given by

(13) $d \ln y_{h}=s_{h}^{e} d \ln p$,

where $d \ln y_{h}$ is the change in income of household $h$ resulting from the price change $d \ln p$, and $s_{h}^{e}$ is the share of income derived from export crops. For a given price change, we use this equation to calculate the changes in household per equivalent adult (assuming all the additional income is consumed) and to recompute the poverty count until the poverty rate declines by between 1.4 and 1.75 percentage points (keeping market density constant). This iterative process reveals non-trivial price-equivalent changes, ranging from 11 to 17 percent. Clearly, significant liberalization of world export markets, or a sizeable growth in demand of Ugandan agricultural exports would be needed to achieve these price changes. While this is a simple exercise, it neatly shows how important the poverty-reducing impacts of lower marking costs can be.

\section{Robustness and Sensitivity}

One of the main concerns with our estimation strategy is that we have relied only on one instrument in the instrumental variables estimator. In order to perform specification tests, we redo the whole analysis using two instruments. To do this, we add export market density in 1995 to our main instrument (the out-of-district cost of transportation to Kampala). This lag captures the fact that markets are sometimes focal points that tend to perpetuate. Although it is fairly common to use lagged variables as instruments, there are some concerns to address. First, it is important to ask if the same correlation between market availability and poverty in $t$ may be present between market availability in $t-T$ and poverty in $t$ (where $T$ is the number of year between household surveys, 1999 and 1995 in this case). For 
instance, if there is autocorrelation in the residuals in (10), then the endogeneity argument that invalidates the results from OLS may also invalidate the results from the use of lagged instruments. Similarly, lagged instruments will not work if there are persistent omitted variables. Here, we claim that the autocorrelation in the errors becomes a second order problem. We are actually merging data from the 1999 UNHS with an instrument taken from the 1995 UNHS. Since four years separate these surveys, there is good reason to believe that the correlation will be practically absent. Another problem is that, since our instrument varies across districts, the instrument is required to be uncorrelated with all lags of the residuals, a requirement that might fail in the presence of district fixed effects. Since we are accounting for district effects by including a comprehensive set of district controls $\mathbf{z}_{c}$, we argue that this requirement is met.

Results are reported in Table 8. The instruments work well, both according to the predictive power in the first stage regression and to the Hansen specification test of overidentifying restrictions. The magnitudes of the impacts are similar to those in previous sections.

Another concern is that the impacts of lower export marketing costs might be different for households already engaged in export crops than for households that choose not to produce exportables. This situation may arise if, for example, there are factors (such as land quality) that might prevent participation in export crops in certain locations, independently of the marketing costs. While our regressions include controls for land quality (at the district level), it is worth exploring this further by performing our analysis on the selected sample, i.e., on the sample of export crop producers. A summary of the main results is in Table 9.

The overall causal link from export markets to poverty can still be found on the sample of export crop producers. In Panels A) and B), we find that lower marketing costs in export agriculture causes household expenditure to increase and poverty to decline. Even though the coefficients are large, they are not strictly comparable to the previous estimates because the samples are different. For example, poverty responds roughly twice as strongly for the selected sample than for the whole sample $(-0.64$ and -0.35 , respectively, in the Probit specification for poverty). However, since about a third of the sample produces export 
crops, the impacts on the aggregate poverty rate would actually be smaller if only the export crop producers are allowed to be affected by higher export market availability. Further, the mechanisms outlined above, from export market availability to adoption and from adoption to poverty, are still observed as well. As expected, however, some of the links are weaker (in a statistical sense) because there is less variation across export producers in land allocation. We conclude that while the overall impacts and channels are present in the selected sample, the impacts are somewhat smaller. This confirms typical findings of this type of literature whereby larger impacts (on poverty, supply responses, etc.) are estimated when the extensive margin is considered on top of the intensive margin (Key, Sadoulet, and de Janvry (2000).

\section{Conclusions}

The main claim of this paper is that the way in which trade affects poverty is shaped by complementarities between export opportunities and domestic factors. In the presence of export opportunities, such as enlarged market access in developed countries or high international prices for major export crops like coffee, tea, cotton and fruits, the potential gains from exports may not be realizable if complementary domestic factors are unavailable. We have explored this hypothesis by investigating the case of intermediation activities, marketing costs, export crop adoption, and poverty in Uganda.

Our findings make two contributions to the related literature. We generate direct evidence that exports matter for poverty reduction: farmers that are able to adopt high-yield export crops are on average less poor than farmers more oriented towards subsistence activities. Further, we provide direct evidence of the importance of complementary policies to the realization of the gains from trade: trade costs matter for poverty reduction because high trade costs prevent farmers from adopting major export crops. This is mostly a transaction costs argument whereby the presence of export markets facilitates the marketing of export crops and allows farmers to fetch a higher net price for their output.

Policies that reduce trade costs and encourage marketing activities in rural areas may be useful to facilitate exports and reduce poverty. Examples include roads, marketing 
information, and measures that promote the development of market arrangements such as FDI (in, for instance, coffee and tea plantations) or outgrower schemes (like the coffee alliance initiative in Uganda). These findings support the recent emphasis on the "aid for trade" approach to development policy. While policies targeting education, health, gender participation and the like are important not only in terms of poverty reduction but also in terms of overall socio-economic development, our results emphasize the potential scope for poverty alleviation via increased export market density. In fact, our findings suggest that the poverty impacts of higher market availability could be sizeable: simple back of the envelope calculations show that they could be equivalent to the poverty impacts of large increases in export prices resulting from, for example, market access to developed countries or other similar instruments as discussed in the Doha Development Agenda.

\section{Appendix A: Two Theoretical Results}

We want to show that both the probability of specializing in export crops and expected income are increasing in the number of intermediaries in a district. That is, that $\pi(p, n)$ and $Y(p, n)$ from equations (8) and (9) are increasing in $n$ when keeping $p$ constant. Both equations can be generically written as an integral of the form

$$
I(p, n)=2 n \int_{0}^{\frac{1}{2 n}} g(p, x) d x
$$

The derivative of the generic integral with respect to the number of intermediaries is

$$
\frac{\partial I(p, n)}{\partial n}=2 \int_{0}^{\frac{1}{2 n}}\left[g(p, x)-g\left(p, \frac{1}{2 n}\right)\right] d x
$$

which is strictly positive for any function $g$ strictly decreasing in $x$.

In the case of the probability of specializing in export crops, $\pi(p, n), g$ is equal to the probability of specializing in export crops at a given distance $x$,

$$
\begin{aligned}
g(p, x) & =1-F(\widetilde{A}(p, x)) \\
& =1-F\left(\frac{R}{p-\delta x}\right) .
\end{aligned}
$$


This function is strictly decreasing in $x$. In the case of expected income $Y(p, n)$

$$
\begin{aligned}
g(p, x) & =F(\widetilde{A}(p, x)) R+p \int_{\widetilde{A}(x, p)}^{\infty} A f(A) d A \\
& =F\left(\frac{R}{p-\delta x}\right) R+p \int_{\frac{R}{p-\delta x}}^{\infty} A f(A) d A,
\end{aligned}
$$

which is also strictly decreasing in $x$. Thus, both $\pi(p, n)$ and $Y(p, n)$ are strictly decreasing in $x$, the result we wanted to show.

\section{Appendix B: Household and District Controls}

Table A1 shows the results of the IV linear model of poverty on market density.

\section{References}

Acemoglu, D., S. Johnson, and J. Robinson (2001). "Colonial Origins of Comparative Development: An Empirical Analysis," The American Economic Review, vol. 91, pp. 1369-1401.

Anderson, J. and E. van Wincoop (2004). "Trade Costs," Journal of Economic Literature, American Economic Association, vol. 42(3), pp. 691-751.

Ashraf, N., X. Giné, and D. Karlan (2008). "Finding Missing Markets (and a disturbing epilogue): Evidence from an Export Crop Adoption and Marketing Intervention in Kenya," Policy Research Working Paper No 4477, The World Bank.

Appleton, (1999). "Poverty Rates in Uganda," mimeo, The World Bank.

Brambilla, I. and G. Porto (2007). "Market Structure, Outgrower Contracts and Farm Output. Evidence from Cotton Reforms in Zambia," mimeo Yale University.

Blundell, R. and J. Powell (2004). "Endogeneity in Semiparametric Binary Response Models," Review of Economic Studies, vol. 71, pp. 655-679.

Card, D. (1999). "The Causal Effect of Education on Earnings," in O. Ashenfelter and D. Card (eds), Handbook of Labor Economics Volume 3A. Amsterdam: Elsevier. 
Collier, P. and J. Gunning (1999). "Explaining African Economic Performance," Journal of Economic Literature, vol. XXXVII, pp. 64-111.

Frankel, J. and D. Romer (1999). "Does Trade Cause Growth?," The American Economic Review, vol. 89, No. 3, pp. 379-399.

Goldberg, P. and N. Pavcnik (2007). "Distributional Effects of Trade Liberalization in Developing Countries," Journal of Economic Literature, 45(1), pp. 39-82.

Goyal, A. (2008). "Information Technology and Rural Markets: Theory and Evidence from a Unique Intervention in Central India," mimeo, University of Maryland.

Harrison, A. (Ed.), (2007). Globalization and Poverty, forthcoming University of Chicago Press for the National Bureau of Economic Research, Boston, Massachusetts.

Hertel, T. and A.L. Winters (Eds.), (2006). Poverty Impacts of the Doha Development Agenda, Palgrave-McMillan for the World Bank, Washington DC.

Hoekman, B. and M. Olarreaga (Eds.), (2007). Global Trade and Poor Nations: Poverty Impacts and Policy Implications of Liberalization, Brookings Institution Press.

Hummels, D. (2001). "Toward a Geography of Trade Costs," mimeo Purdue University.

Jensen, R. (2007). "The Digital Provide: Information (Technology), Market Performance, and Welfare in the South Indian Fisheries Sector," Quaterly Journal of Economics, Vol. CXXII, Issue 3, pp. 879-924.

Key, N., E. Sadoulet and A. de Janvry (2000). "Transactions Costs and Agricultural Household Supply Response," American Journal of Agricultural Economics, 82, pp. 245-259.

Kranton, R. and A. Swamy (2008). "Contracts, Hold-Up, and Exports: Textiles and Opium in Colonial India," forthcoming American Economic Review.

Limão, N. and A. Venables, (2001). "Infrastructure, Geographical Disadvantage, and Transport Costs," World Bank Economic Review, Vol. 15, No 3, pp. 451-479. 
Newey, W. (1987). "Efficient Estimation of Limited Dependent Variable Models with Endogenous Explanatory Variables," Journal of Econometrics 36, pp. 231-250.

Nicita, A. (2008). "The Price Effect of Trade Liberalization: Measuring the Impacts on Household welfare," forthcoming Journal of Development Economics.

Pagan, A. and A. Ullah (1999). Nonparametric Econometrics. Cambridge University Press, New York.

Porto, G. (2005). "Informal Export Barriers and Poverty," Journal of International Economics, 66, pp. 447-470.

Stock, J. and D. Staiger (1997). "Instrumental Variables Regression with Weak Instruments," Econometrica 65, No 3, pp. 557-586.

Welch, K., M. McMillan and D. Rodrik (2003). "When Economic Reform Goes Wrong: Cashews in Mozambique," Brookings Trade Forum 2003.

Winters, A., N. McCulloch, and A. McKay (2004). "Trade Liberalization and Poverty: The Evidence So Far," Journal of Economic Literature, XLII, pp. 72-115. 


\section{Figure 1}

\section{Supply faced by an Intermediary}

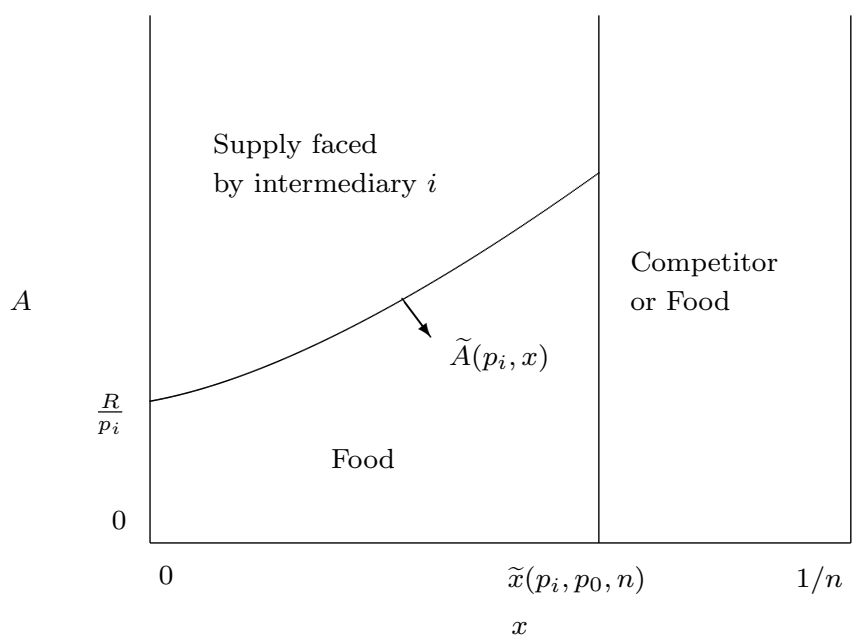

Note: An intermediary and its right competitor compete for farmers located in $[0,1 / n]$. Some of these farmers choose to produce food crops. At given prices, the fraction of farmers that sell export crops to intermediary $i$ is given by the area to the left of $\widetilde{x}$ and above $\widetilde{A}$.

Figure 2

\section{Equilibrium}

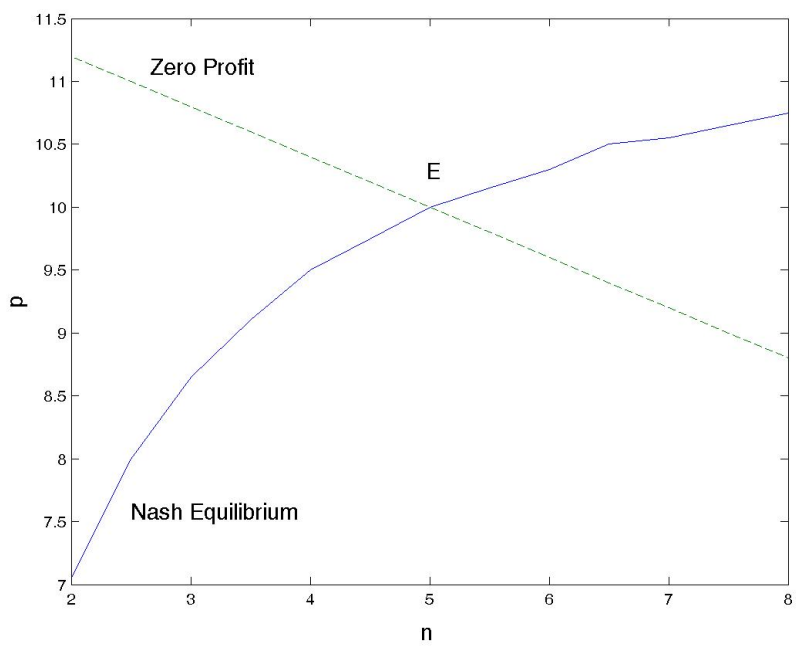

Note: Simulation of the Profit Maximization and Zero Profit combinations of price and number of intermediaries under an exponential distribution of returns to export crops; $f(A)=\lambda e^{-\lambda A}$. The parameter values are: $\lambda=0.2, R=4, \delta=10, P^{*}=13, D=2$, $d=1$. 
Figure 3

Export Crop Activity in Uganda

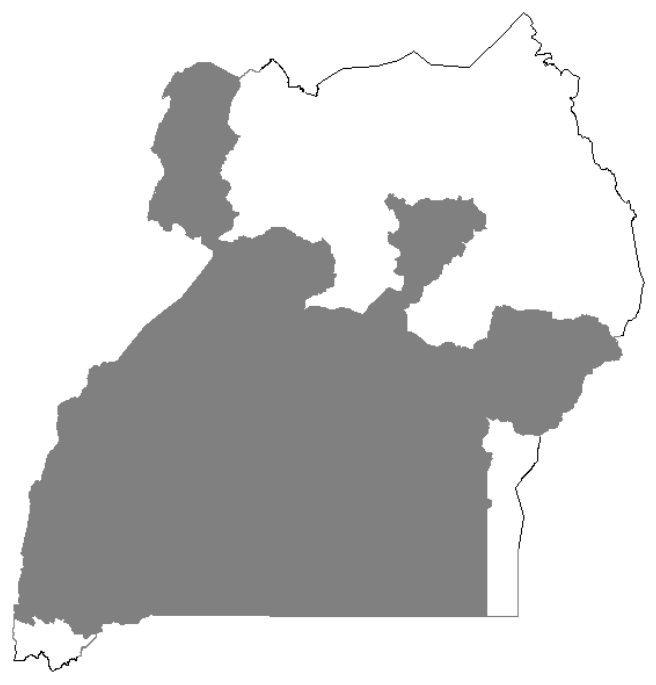

a) Coffee

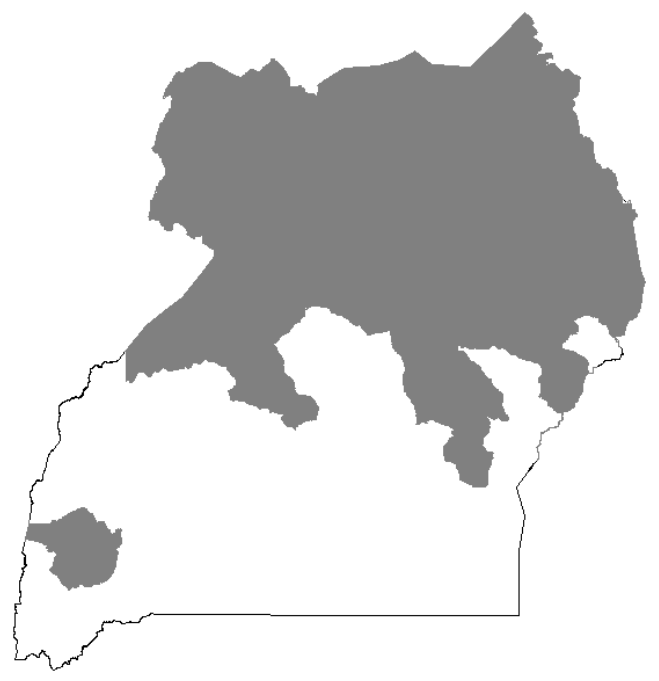

c) Cotton

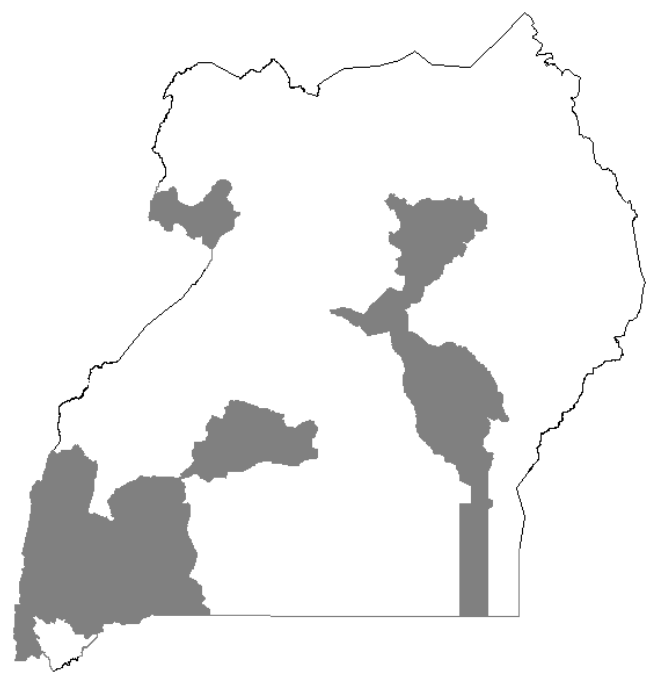

b) Tea

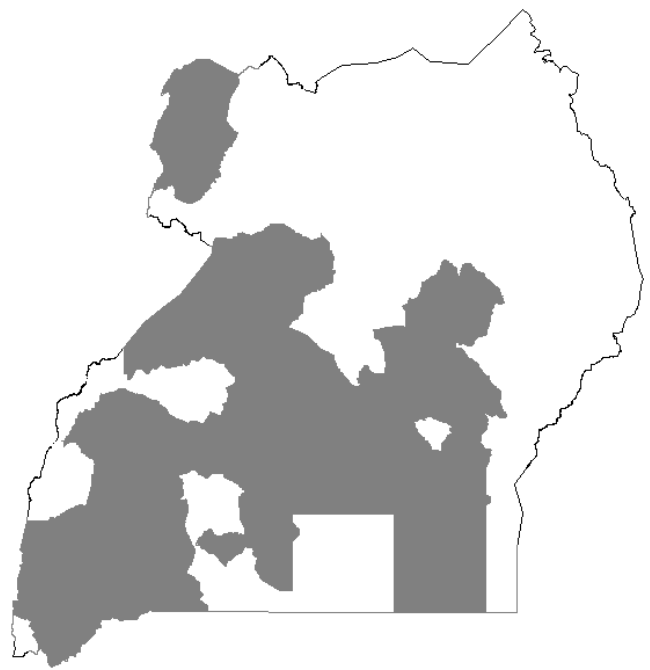

d) Passion fruit \& Pineapple

Note: The maps show the geographical distribution of export crop production in Uganda. They were built based on the crop module from the Uganda National Household Survey (1999) and FAO Country Profiles and Mapping Information System. 


\section{Figure 4}

\section{Agriculture Produce Markets, Exports and Poverty}
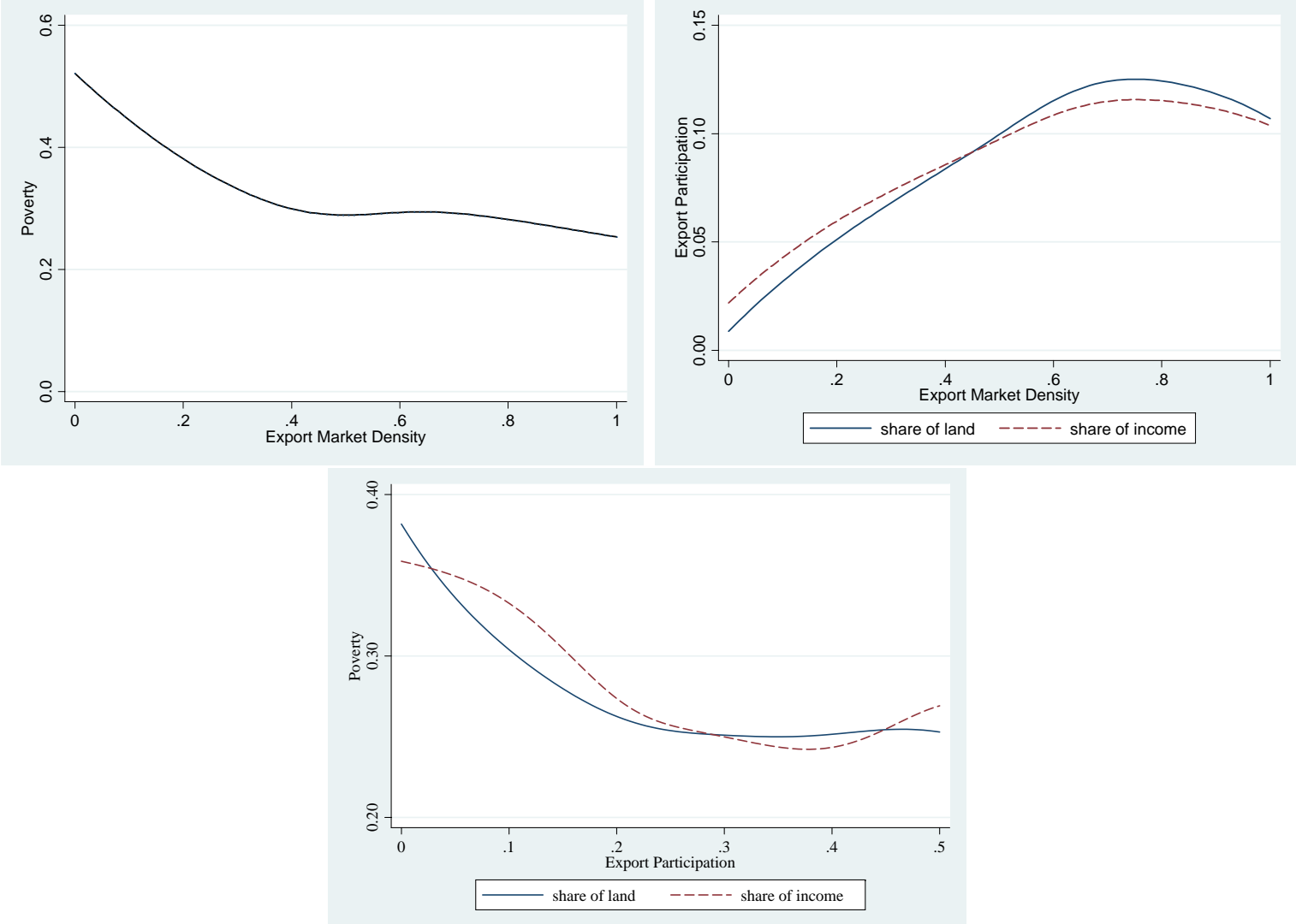

Note: The graphs report non-parametric regressions. The estimates are obtained with a Fan locally weighted linear regression. We use a Gaussian kernel and bandwidths of $0.15,0.15$, and 0.05 . 
Figure 5

Export Prices and Export Market Density

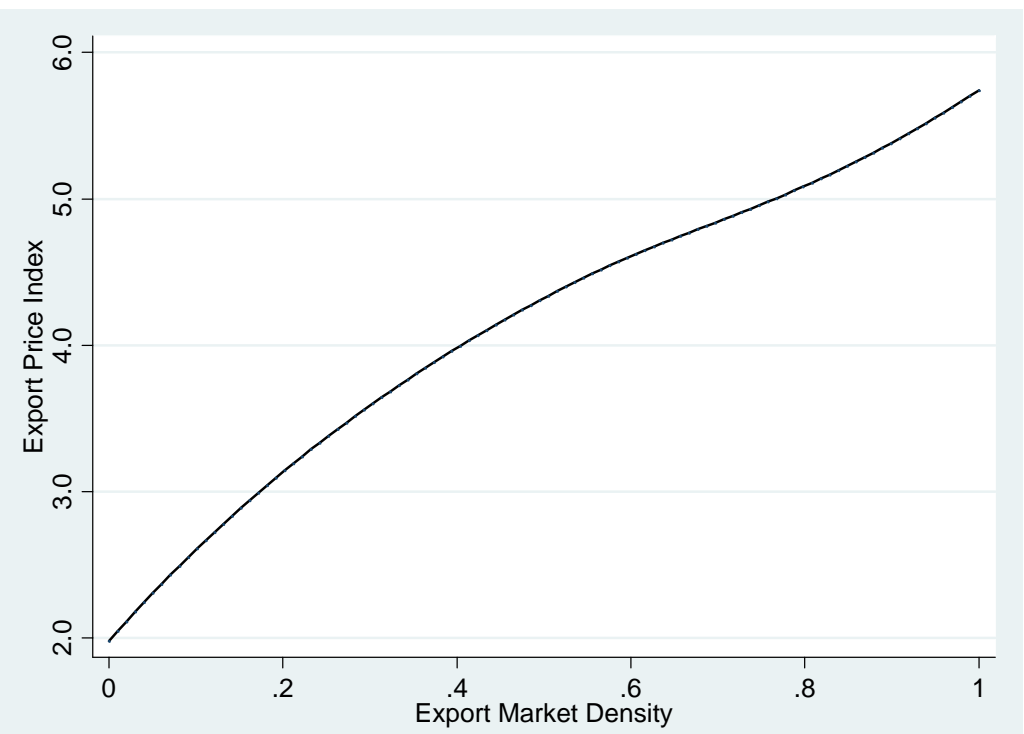

Note: The graph reports a non-parametric regression of the export price index on export market density. The estimates are obtained with a Fan locally weighted linear regression. We use a Gaussian kernel and bandwidths of 0.15 . 
Table 1

Summary Statistics. Uganda National Household Survey

\begin{tabular}{|c|c|c|}
\hline & Average & Std. Dev \\
\hline \multicolumn{3}{|l|}{ HOUSEHOLD CHARACTERISTICS } \\
\hline Household size & 5.67 & 3.05 \\
\hline Male heads & 0.74 & 0.44 \\
\hline Married heads & 0.71 & 0.45 \\
\hline Males & 0.49 & 0.22 \\
\hline Age $18-45$ & 0.30 & 0.23 \\
\hline Age 46- & 0.16 & 0.26 \\
\hline Age $0-5$ & 0.19 & 0.18 \\
\hline Age 6-12 & 0.22 & 0.18 \\
\hline Age $12-18$ & 0.13 & 0.16 \\
\hline \multicolumn{3}{|l|}{ POVERTY } \\
\hline Monthly per equivalent adult expenditure (PPP US\$) & 42.64 & 38.70 \\
\hline Urban poverty line $(\mathrm{PPP} U \mathrm{US} \$)^{1}$ & 38.09 & \\
\hline Rural poverty line (PPP US $\$)^{2}$ & 31.44 & \\
\hline Poverty rate & 35.2 & \\
\hline \multicolumn{3}{|l|}{ EXPORT PARTICIPATION } \\
\hline Cultivated land (in acres) & 2.57 & 3.52 \\
\hline Share of land in export crops & 0.07 & 0.17 \\
\hline Share of income from export crops & 0.08 & 0.17 \\
\hline \multicolumn{3}{|l|}{ HEALTH } \\
\hline Proportion of sick members & 0.31 & 0.30 \\
\hline Proportion of sick children & 0.25 & 0.34 \\
\hline Sick mother & 0.22 & 0.42 \\
\hline Number of children & 2.63 & 1.97 \\
\hline Sick mother $*$ number of children & 0.63 & 1.61 \\
\hline \multicolumn{3}{|l|}{ INCOME \& ASSETS $^{3}$} \\
\hline Remittances & 0.48 & 0.50 \\
\hline Non-farm income & 0.35 & 0.48 \\
\hline Animal assets & 0.71 & 0.45 \\
\hline Equipment assets & 0.99 & 0.08 \\
\hline
\end{tabular}

Note: own calculations from the Uganda National Household Survey (UNHS) 1999/2000.

1. The urban poverty line is equivalent to 1.27 PPP US dollars per day.

2. The rural poverty line is equivalent to 1.05 PPP US dollars per day.

3. National averages are constructed from dichotomous variables at the household level that indicate whether

a household received remittances or not, etc. 
Table 2

Major Exports in Uganda (1999-2000)

\begin{tabular}{|c|c|c|}
\hline \multirow[t]{2}{*}{ Main Products } & \multicolumn{2}{|c|}{ Export Shares } \\
\hline & 1999 & 2000 \\
\hline Coffee & 60.2 & 31.2 \\
\hline Cotton & 3.64 & 5.5 \\
\hline Tea & 4.48 & 9.22 \\
\hline Tobacco & 3.06 & 6.69 \\
\hline Fish & 5.19 & 7.67 \\
\hline Fruits & 0.14 & 0.18 \\
\hline Flowers & 1.53 & 2.47 \\
\hline Total & 77.94 & 62.93 \\
\hline
\end{tabular}

Note: Uganda Bureau of Statistics. Compiled by the

Uganda Export Promotion Board. 
Table 3

Summary Statistics: Uganda National Household Survey

Market Density and Village Controls

\begin{tabular}{lcc}
\hline \hline & Average & Std. Dev. \\
\hline MARKET DENSITY & & \\
Export crops & 0.37 & 0.31 \\
Food & 0.76 & 0.24 \\
& & \\
DISTRICT CONTROLS ${ }^{1}$ & & \\
Distance to paved road & 25.90 & 21.28 \\
Access to credit & 0.68 & 0.30 \\
Access to improved seeds & 0.58 & 0.28 \\
Access to oxen & 0.26 & 0.36 \\
Access to oxen rental & 0.21 & 0.31 \\
Access to tractors & 0.12 & 0.18 \\
Access to extension services & 0.38 & 0.24 \\
Output market constraints & 0.15 & 0.14 \\
Input market constraints & 0.16 & 0.12 \\
Road constraints & 0.05 & 0.08 \\
Disease constraints & 0.22 & 0.18 \\
Security constraints & 0.01 & 0.03 \\
Land constraints & 0.15 & 0.20 \\
Credit constraints & 0.04 & 0.08 \\
Land fertility constraints & 0.08 & 0.09 \\
Access to veterinary services & 0.28 & 0.26 \\
Land conflict & 0.13 & 0.12 \\
Land community & 0.08 & 0.23 \\
Access to primary school & 0.49 & 0.21 \\
Free medicine & 0.43 & 0.32 \\
Election & 0.11 & 0.18 \\
Access to water & 0.53 & 0.21 \\
Public hospital & 0.27 & 0.20 \\
Private hospital & 0.32 & 0.23 \\
\hline \hline
\end{tabular}

Note: own calculations from the Uganda National Household Survey (UNHS) 1999/2000.

1. All district variables except distance to paved roads are constructed from dichotomous variables at the community level. 
Table 4

Poverty and Market Density

Instrumental Variables

\begin{tabular}{|c|c|c|c|}
\hline & Model 1 & Model 2 & Model 3 \\
\hline \multicolumn{4}{|l|}{ IV - Linear Model } \\
\hline Export Market Density & $\begin{array}{c}-0.56 \\
(0.11)^{* * *}\end{array}$ & $\begin{array}{c}-0.27 \\
(0.13)^{* *}\end{array}$ & $\begin{array}{c}-0.28 \\
(0.13)^{* *}\end{array}$ \\
\hline Export Price Index & - & $\begin{array}{c}-0.01 \\
(0.009)\end{array}$ & $\begin{array}{c}-0.01 \\
(0.009)\end{array}$ \\
\hline Food Market Density & - & - & $\begin{array}{c}-0.011 \\
(0.02)\end{array}$ \\
\hline Household characteristics & Yes & Yes & Yes \\
\hline District characteristics & No & Yes & Yes \\
\hline$R^{2}$ & 0.11 & 0.21 & 0.21 \\
\hline First stage coefficient & -0.038 & -0.027 & -0.028 \\
\hline Standard error & $(0.006)^{* * *}$ & $(0.008)^{* * *}$ & $(0.008)^{* * *}$ \\
\hline$R^{2}$ & 0.37 & 0.76 & 0.77 \\
\hline \multicolumn{4}{|l|}{ OLS } \\
\hline Export Market Density & $\begin{array}{c}-0.27 \\
(0.06)^{* * *}\end{array}$ & $\begin{array}{c}-0.12 \\
(0.04)^{* *}\end{array}$ & $\begin{array}{c}-0.11 \\
(0.04)^{* *}\end{array}$ \\
\hline$R^{2}$ & 0.14 & 0.21 & 0.21 \\
\hline \multicolumn{4}{|l|}{ IV - Probit } \\
\hline Export Market Density & -1.71 & -0.97 & -0.98 \\
\hline Marginal effect & -0.62 & -0.35 & -0.35 \\
\hline Standard error (marg. effects) & $(0.12)^{* * *}$ & $(0.15)^{* * *}$ & $(0.15)^{* * *}$ \\
\hline$R^{2}$ & 0.18 & 0.18 & 0.18 \\
\hline \multicolumn{4}{|c|}{ IV - per equivalent adult expenditure } \\
\hline Export Market Density & $\begin{array}{c}1.14 \\
(0.20)^{* * *}\end{array}$ & $\begin{array}{c}0.73 \\
(0.23)^{* * *}\end{array}$ & $\begin{array}{c}0.73 \\
(0.24)^{* * *}\end{array}$ \\
\hline$R^{2}$ & 0.32 & 0.39 & 0.40 \\
\hline Observations & 6734 & 6743 & 6743 \\
\hline
\end{tabular}

Note: The dependent variable in the first three panels is a dichotomous indicator of whether the household is poor or not. In the last panel, the dependent variable is the log of per equivalent adult expenditure of the household. The main independent variable is export market density, which measures market availability for export agriculture produce.

The first panel reports results from 2SLS of poverty on market density. We report the coefficient, the cluster-corrected standard errors, the $R^{2}$, and results from the first stage regression. The second panel reports OLS estimates from the same model. The third panel reports estimates from a probit model with endogenous regressor (using the control function approach). We report the coefficient, the marginal effects with their cluster-corrected standard errors, and the pseudo $R^{2}$. Finally, the last panel includes IV results for log per equivalent adult expenditure.

Based on the Uganda National Household Survey 1999/2000. 
Table 5

Export Participation and Market Density Share of Land

\begin{tabular}{|c|c|c|c|}
\hline & Model 1 & Model 2 & Model 3 \\
\hline $\begin{array}{l}\text { IV - Linear Model } \\
\text { Coefficient } \\
\text { Standard error } \\
R^{2}\end{array}$ & $\begin{array}{c}0.30 \\
(0.052)^{* * *} \\
0.13\end{array}$ & $\begin{array}{c}0.18 \\
(0.07)^{* * *} \\
0.21\end{array}$ & $\begin{array}{c}0.18 \\
(0.07)^{* * *} \\
0.21\end{array}$ \\
\hline $\begin{array}{l}\text { IV - Tobit } \\
\text { Marginal effect } \\
\text { Standard error }\end{array}$ & $\begin{array}{c}0.31 \\
(0.040)^{* * *}\end{array}$ & $\begin{array}{c}0.18 \\
(0.052)^{* * *}\end{array}$ & $\begin{array}{c}0.18 \\
(0.050)^{* * *}\end{array}$ \\
\hline Observations & 6554 & 6554 & 6554 \\
\hline $\begin{array}{l}\text { Export Price Index } \\
\text { Food Markets } \\
\text { Household characteristics } \\
\text { District characteristics }\end{array}$ & $\begin{array}{l}\text { No } \\
\text { No } \\
\text { Yes } \\
\text { No }\end{array}$ & $\begin{array}{l}\text { Yes } \\
\text { No } \\
\text { Yes } \\
\text { Yes }\end{array}$ & $\begin{array}{l}\text { Yes } \\
\text { Yes } \\
\text { Yes } \\
\text { Yes }\end{array}$ \\
\hline
\end{tabular}

Note: Export participation is measured with the share of land devoted to export crops (coffee, tea, cotton, pineapples, passion fruit).

The first panel shows results from 2SLS regressions of export participation on export market density. The second panel shows MLE results from a Tobit specification with endogenous variables (using the control function approach). Standard errors (within parenthesis) are cluster-corrected.

Based on the Uganda National Household Survey 1999/2000. 
Table 6

Export Participation and Market Density Share of Income

\begin{tabular}{lccc}
\hline \hline & Model 1 & Model 2 & Model 3 \\
\hline $\begin{array}{l}\text { IV - Linear Model } \\
\text { Coefficient }\end{array}$ & 0.29 & 0.14 & 0.14 \\
$\quad \begin{array}{c}\text { Standard error } \\
R^{2}\end{array}$ & $(0.05)^{* * *}$ & $(0.06)^{* *}$ & $(0.06)^{* *}$ \\
& 0.14 & 0.14 & 0.14 \\
\hline IV - Tobit & & & \\
$\quad$ Marginal effect & 0.35 & 0.29 & 0.29 \\
$\quad$ Standard error & $(0.057)^{* * *}$ & $(0.049)^{* * *}$ & $(0.049)^{* * *}$ \\
\hline Observations & 6606 & 6606 & 6606 \\
& & & \\
Export Price Index & No & Yes & Yes \\
Food Markets & No & No & Yes \\
Household characteristics & Yes & Yes & Yes \\
District characteristics & No & Yes & Yes \\
\hline \hline
\end{tabular}

Note: Export participation is measured with the share of income generated by export crops (coffee, tea, cotton, pineapples, passion fruit).

The first panel shows results from 2SLS regressions of export participation on export market density. The second panel shows MLE results from a Tobit specification with endogenous variables (using the control function approach). Standard errors (within parenthesis) are cluster-corrected.

Based on the Uganda National Household Survey 1999/2000. 


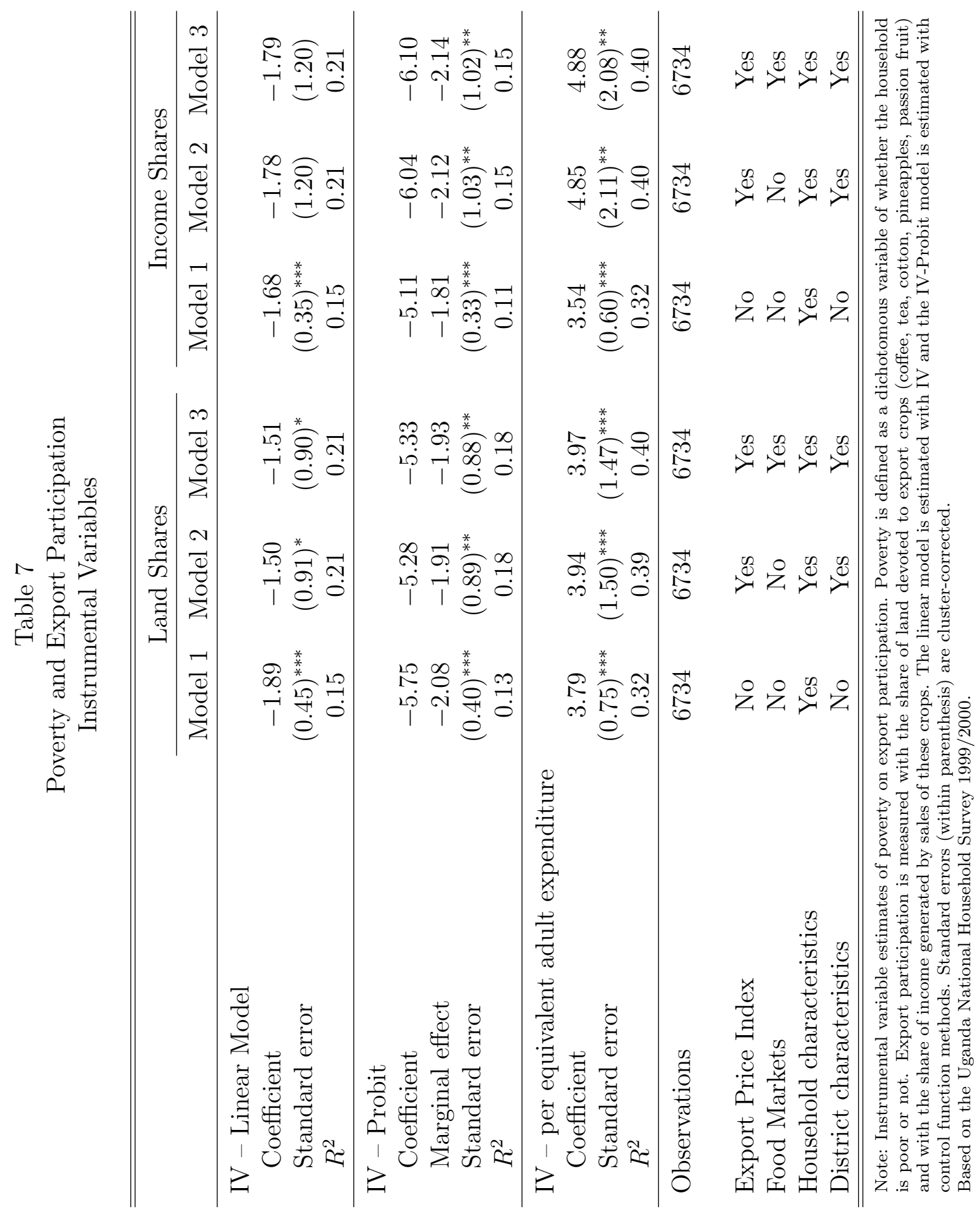


Table 8

Robustness to Set of Instruments

Two Instruments

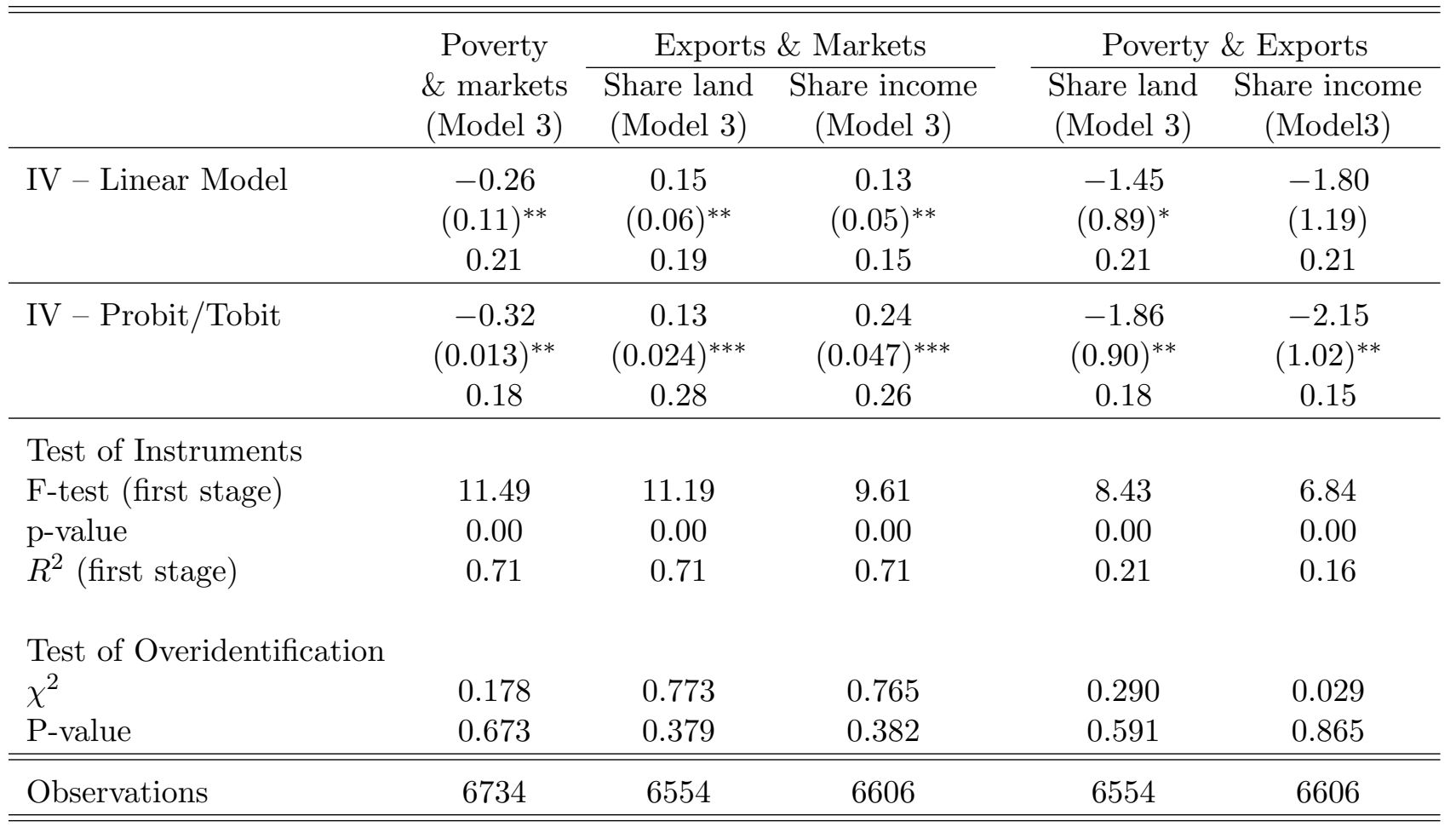

Note: Instrumental variable estimates using two instruments, the out-of-district cost of transportation to Kampala and the lagged export market density in 1995. Poverty is defined as a dichotomous variable of whether the household is poor or not. Export participation is measured with the share of land devoted to export crops (coffee, tea, cotton, pineapples, passion fruit) and with the share of income generated by sales of these crops. The linear model is estimated with IV and the IV-Probit model is estimated with control function methods. Standard errors (within parenthesis) are cluster-corrected. Based on the Uganda National Household Survey 1995/96 and 1999/2000. 
Table 9

Export Crops, Marketing Costs, and Poverty

Impacts of Export Crop Producers

Instrumental Variables

\begin{tabular}{|c|c|c|c|}
\hline & Model 1 & Model 2 & Model 3 \\
\hline \multicolumn{4}{|l|}{ A) Poverty and Markets } \\
\hline \multirow[t]{2}{*}{ IV } & -0.95 & -0.61 & -0.60 \\
\hline & $(0.19)^{* * *}$ & $(0.31)^{* *}$ & $(0.30)^{* *}$ \\
\hline$R^{2}$ & 0.21 & 0.26 & 0.26 \\
\hline \multirow[t]{2}{*}{ IV-Probit (marg. effect) } & -1.08 & -0.65 & -0.64 \\
\hline & $(0.17)^{* * *}$ & $(0.33)^{* *}$ & $(0.32)^{* * *}$ \\
\hline$R^{2}$ & 0.18 & 0.23 & 0.23 \\
\hline \multicolumn{4}{|l|}{ B) Expenditures and Markets } \\
\hline \multirow[t]{2}{*}{ IV } & 1.80 & 1.44 & 1.44 \\
\hline & $(0.32)^{* * *}$ & $(0.52)^{* *}$ & $(0.52)^{* *}$ \\
\hline$R^{2}$ & 0.41 & 0.46 & 0.46 \\
\hline \multicolumn{4}{|c|}{ C) Export Participation and Markets } \\
\hline \multirow[t]{2}{*}{ IV } & 0.53 & 0.24 & 0.24 \\
\hline & $(0.11)^{* * *}$ & $(0.14)^{*}$ & $(0.14)^{*}$ \\
\hline$R^{2}$ & 0.15 & 0.21 & 0.21 \\
\hline \multicolumn{4}{|c|}{ D) Poverty and Export Participation } \\
\hline \multirow[t]{2}{*}{ IV-Probit (marg. effect) } & -2.05 & -2.65 & -2.64 \\
\hline & $(0.32)^{* * *}$ & $(1.49)^{*}$ & $(1.50)^{*}$ \\
\hline$R^{2}$ & 0.18 & 0.23 & 0.23 \\
\hline \multicolumn{4}{|c|}{ E) Expenditures and Export Participation } \\
\hline \multirow[t]{2}{*}{ IV } & 3.39 & 6.62 & 6.17 \\
\hline & $(0.51)^{* * *}$ & $(3.27)^{*}$ & $(3.28)^{*}$ \\
\hline$R^{2}$ & 0.41 & 0.46 & 0.46 \\
\hline Observations & 2545 & 2545 & 2545 \\
\hline
\end{tabular}


Table A1

Poverty and Market Density

Household and District Controls

Instrumental Variables Linear Model

\begin{tabular}{|c|c|c|c|}
\hline & Model 1 & Model 2 & Model 3 \\
\hline Household size & $\begin{array}{c}0.0198 \\
(0.003)^{* * *}\end{array}$ & $\begin{array}{c}0.0201 \\
(0.003)^{* * *}\end{array}$ & $\begin{array}{c}0.0201 \\
(0.003)^{* * *}\end{array}$ \\
\hline Male head & $\begin{array}{c}0.0092 \\
(0.0272)\end{array}$ & $\begin{array}{c}0.0348 \\
(0.0221)\end{array}$ & $\begin{array}{c}0.0351 \\
(0.0221)\end{array}$ \\
\hline Male married & $\begin{array}{c}-0.0003 \\
(0.0093)\end{array}$ & $\begin{array}{c}0.0081 \\
(0.0086)\end{array}$ & $\begin{array}{c}0.0081 \\
(0.0086)\end{array}$ \\
\hline Number of males & $\begin{array}{c}0.0952 \\
(0.029)^{* * *}\end{array}$ & $\begin{array}{c}0.0937 \\
(0.0271)^{* * *}\end{array}$ & $\begin{array}{c}0.0934 \\
(0.0269)^{* * *}\end{array}$ \\
\hline Age $12-18$ & $\begin{array}{c}0.2959 \\
(0.0558)^{* * *}\end{array}$ & $\begin{array}{c}0.2884 \\
(0.0508)^{* * *}\end{array}$ & $\begin{array}{c}0.2882 \\
(0.0508)^{* * *}\end{array}$ \\
\hline Age $46+$ & $\begin{array}{c}0.0386 \\
(0.0326)\end{array}$ & $\begin{array}{c}0.0399 \\
(0.0283)\end{array}$ & $\begin{array}{c}0.0401 \\
(0.0281)\end{array}$ \\
\hline Age $0-5$ & $\begin{array}{c}0.2520 \\
(0.0498)^{* * *}\end{array}$ & $\begin{array}{c}0.2327 \\
(0.0490)^{* * *}\end{array}$ & $\begin{array}{c}0.2327 \\
(0.0491)^{* * *}\end{array}$ \\
\hline Age 6-12 & $\begin{array}{c}0.4344 \\
(0.0539)^{* * *}\end{array}$ & $\begin{array}{c}0.4142 \\
(0.0544)^{* * *}\end{array}$ & $\begin{array}{c}0.4139 \\
(0.0543)^{* * *}\end{array}$ \\
\hline Literacy of head & $\begin{array}{c}-0.0873 \\
(0.0285)^{* * *}\end{array}$ & $\begin{array}{c}-0.0639 \\
(0.0258)^{* *}\end{array}$ & $\begin{array}{c}-0.0637 \\
(0.0258)^{* *}\end{array}$ \\
\hline Education (no schooling) & $\begin{array}{l}-0.0043 \\
(0.0737)\end{array}$ & $\begin{array}{c}-0.0040 \\
(0.0769)\end{array}$ & $\begin{array}{l}-0.0037 \\
(0.0765)\end{array}$ \\
\hline Education (primary incomplete) & $\begin{array}{l}-0.0163 \\
(0.0743)\end{array}$ & $\begin{array}{l}-0.0155 \\
(0.0758)\end{array}$ & $\begin{array}{l}-0.0155 \\
(0.0756)\end{array}$ \\
\hline Education (primary complete) & $\begin{array}{c}-0.1093 \\
(0.0785)\end{array}$ & $\begin{array}{c}-0.1011 \\
(0.0781)\end{array}$ & $\begin{array}{l}-0.1008 \\
(0.0777)\end{array}$ \\
\hline Education (junior incomplete) & $\begin{array}{c}-0.1870 \\
(0.0792)^{* *}\end{array}$ & $\begin{array}{c}-0.1822 \\
(0.0791)^{* *}\end{array}$ & $\begin{array}{c}-0.1819 \\
(0.0788)^{* *}\end{array}$ \\
\hline Education (junior complete) & $\begin{array}{c}-0.1561 \\
(0.0832)^{*}\end{array}$ & $\begin{array}{c}-0.1494 \\
(0.0920)\end{array}$ & $\begin{array}{l}-0.1498 \\
(0.0919)\end{array}$ \\
\hline Education (senior incomplete) & $\begin{array}{c}-0.1690 \\
(0.0710)^{* *}\end{array}$ & $\begin{array}{c}-0.1605 \\
(0.0704)^{* *}\end{array}$ & $\begin{array}{c}-0.1602 \\
(0.0700)^{* *}\end{array}$ \\
\hline Education (senior complete) & $\begin{array}{c}-0.3265 \\
(0.0794)^{* * *}\end{array}$ & $\begin{array}{c}-0.2996 \\
(0.0782)^{* * *}\end{array}$ & $\begin{array}{c}-0.2991 \\
(0.0776)^{* * *}\end{array}$ \\
\hline Education (superior) & $\begin{array}{c}0.3329 \\
(0.1093)^{* * *}\end{array}$ & $\begin{array}{c}-0.2515 \\
(0.095)^{* * *}\end{array}$ & $\begin{array}{c}-0.2509 \\
(0.095)^{* * *}\end{array}$ \\
\hline Health status (head) & $\begin{array}{l}-0.0239 \\
(0.0177)\end{array}$ & $\begin{array}{c}-0.0394 \\
(0.0127)^{* * *}\end{array}$ & $\begin{array}{c}-0.0396 \\
(0.0129)^{* * *}\end{array}$ \\
\hline
\end{tabular}

Note: Estimates of household and district controls from the model of poverty on export market density. Instrumental variables. Standard errors within parenthesis $(*$ : significant at $10 \%$ level; **: significant at $5 \%$ level; $* * *$ : significant at $1 \%$ level). 
Table A1 (continued)

Poverty and Market Density: Household and District Controls

\begin{tabular}{|c|c|c|c|}
\hline & Model 1 & Model 2 & Model 3 \\
\hline \multirow[t]{2}{*}{ Access to credit } & - & 0.0238 & 0.0242 \\
\hline & - & $(0.0784)$ & $(0.0785)$ \\
\hline \multirow[t]{2}{*}{ Access to improved seeds } & - & -0.0514 & -0.0498 \\
\hline & - & $(0.0582)$ & $(0.0581)$ \\
\hline \multirow[t]{2}{*}{ Access to oxen } & - & 0.5457 & 0.5474 \\
\hline & - & $(0.1423)^{* * *}$ & $(0.1420)^{* * *}$ \\
\hline \multirow[t]{2}{*}{ Access to oxen rental } & - & -0.3474 & -0.3496 \\
\hline & - & $(0.1240)^{* * *}$ & $(0.1236)^{* * *}$ \\
\hline \multirow[t]{2}{*}{ Access to tractors } & - & -0.0303 & -0.0293 \\
\hline & - & $(0.0775)$ & $(0.0779)$ \\
\hline \multirow[t]{2}{*}{ Input market constraints } & - & -0.1478 & -0.1464 \\
\hline & - & $(0.1087)$ & $(0.1087)$ \\
\hline \multirow[t]{2}{*}{ Road constraints } & - & -0.3497 & -0.3430 \\
\hline & - & $(0.1626)^{* *}$ & $(0.1612)^{* *}$ \\
\hline \multirow[t]{2}{*}{ Disease constraints } & - & -0.1714 & -0.1720 \\
\hline & - & $(0.0882)^{* *}$ & $(0.0888)^{* *}$ \\
\hline \multirow[t]{2}{*}{ Security constraints } & - & -0.0931 & -0.1027 \\
\hline & - & $(0.3473)$ & $(0.3472)$ \\
\hline \multirow[t]{2}{*}{ Land constraints } & - & -0.2025 & -0.2041 \\
\hline & - & $(0.0876)^{* *}$ & $(0.0883)^{* *}$ \\
\hline \multirow[t]{2}{*}{ Credit constraints } & - & 0.0795 & 0.0822 \\
\hline & - & $(0.2751)$ & $(0.2732)$ \\
\hline \multirow[t]{2}{*}{ Land fertility constraints } & - & -0.3894 & -0.3880 \\
\hline & - & $(0.1364)^{* * *}$ & $(0.1376)^{* * *}$ \\
\hline \multirow[t]{2}{*}{ Access to veterinary services } & - & 0.1477 & 0.1469 \\
\hline & - & $(0.0677)^{* * *}$ & $(0.0678)^{* * *}$ \\
\hline \multirow[t]{2}{*}{ Land conflict } & - & 0.2058 & 0.2071 \\
\hline & - & $(0.0840)^{* *}$ & $(0.0843)^{* *}$ \\
\hline \multirow[t]{2}{*}{ Land community } & - & -0.1178 & -0.1215 \\
\hline & - & $(0.0602)^{*}$ & $(0.0613)^{*}$ \\
\hline \multirow[t]{2}{*}{ Access to primary school } & - & -0.0152 & -0.0141 \\
\hline & - & $(0.0519)$ & $(0.0521)$ \\
\hline \multirow[t]{2}{*}{ Free medicine } & - & -0.1112 & -0.1100 \\
\hline & - & $(0.0460)^{* *}$ & $(0.0455)^{* *}$ \\
\hline \multirow[t]{2}{*}{ Election } & - & -0.1455 & -0.1419 \\
\hline & - & $(0.0856)^{*}$ & $(0.0847)^{*}$ \\
\hline \multirow[t]{2}{*}{ Access to water } & - & 0.0885 & 0.0886 \\
\hline & - & $(0.0737)$ & $(0.0734)$ \\
\hline \multirow[t]{2}{*}{ Public hospital } & - & -0.1023 & -0.1048 \\
\hline & - & $(0.1229)$ & $(0.1221)$ \\
\hline \multirow[t]{2}{*}{ Private hospital } & - & -0.1142 & -0.1150 \\
\hline & - & $(0.0722)^{*}$ & $(0.0725)^{*}$ \\
\hline Observations & 6734 & 6734 & 6734 \\
\hline R-squared & 0.11 & 0.21 & 0.21 \\
\hline
\end{tabular}

Note: Estimates of household and district controls from the model of poverty on export market density. Instrumental variables. Standard errors within parenthesis (*: significant at $10 \%$ level; $* *$ : significant at $5 \%$ level; $* * *$ : significant at $1 \%$ level). 